\title{
Technical note: Mineralogical, chemical, morphological, and optical interrelationships of mineral dust re-suspensions
}

\author{
Johann P. Engelbrecht ${ }^{1}$, Hans Moosmüller ${ }^{1}$, Samuel Pincock ${ }^{1}$, R. K. M. Jayanty ${ }^{2}$, Traci Lersch ${ }^{3}$, and Gary Casuccio ${ }^{3}$ \\ ${ }^{1}$ Desert Research Institute (DRI), Reno, Nevada 89512-1095, USA \\ ${ }^{2}$ RTI International, Raleigh, North Carolina 27675-9000, USA \\ ${ }^{3}$ RJ Lee Group, Inc., Monroeville, Pennsylvania 15146, USA
}

Correspondence to: Johann P. Engelbrecht (johann@dri.edu)

Received: 2 April 2016 - Published in Atmos. Chem. Phys. Discuss.: 22 April 2016

Revised: 1 August 2016 - Accepted: 8 August 2016 - Published: 31 August 2016

\begin{abstract}
This paper promotes an understanding of the mineralogical, chemical, and physical interrelationships of re-suspended mineral dusts collected as grab samples from global dust sources. Surface soils were collected from arid regions, including the southwestern USA, Mali, Chad, Morocco, Canary Islands, Cabo Verde, Djibouti, Afghanistan, Iraq, Kuwait, Qatar, UAE, Serbia, China, Namibia, Botswana, Australia, and Chile. The $<38 \mu \mathrm{m}$ sieved fraction of each sample was re-suspended in a chamber, from which the airborne mineral dust could be extracted, sampled, and analyzed. Instruments integrated into the entrainment facility included two $\mathrm{PM}_{10}$ and two $\mathrm{PM}_{2.5}$ filter samplers, a beta attenuation gauge for the continuous measurement of $\mathrm{PM}_{10}$ and $\mathrm{PM}_{2.5}$ particulate mass fractions, an aerodynamic particle size analyzer, and a three-wavelength $(405,532,781 \mathrm{~nm})$ photoacoustic instrument with integrating reciprocal nephelometer for monitoring absorption and scattering coefficients during the dust re-suspension process. Filter sampling media included Teflon ${ }^{\circledR}$ membrane and quartz fiber filters for chemical analysis and Nuclepore ${ }^{\circledR}$ filters for individual particle analysis by scanning electron microscopy (SEM). The $<38 \mu \mathrm{m}$ sieved fractions were also analyzed by $\mathrm{X}$-ray diffraction for their mineral content while the $>75$, $<125 \mu \mathrm{m}$ soil fractions were mineralogically assessed by optical microscopy. Presented here are results of the optical measurements, showing the interdependency of singlescattering albedos (SSA) at three different wavelengths and mineralogical content of the entrained dust samples. To explain the elevated concentrations of iron $(\mathrm{Fe})$ and $\mathrm{Fe} / \mathrm{Al}$ ratios in the soil re-suspensions, we propose that dust particles are to a large extent composed of nano-sized particles of mi-
\end{abstract}

cas, clays, metal oxides, and ions of potassium $\left(\mathrm{K}^{+}\right)$, calcium $\left(\mathrm{Ca}^{2+}\right)$, and sodium $\left(\mathrm{Na}^{+}\right)$evenly dispersed as a colloid or adsorbed in amorphous clay-like material. Also shown are differences in SSA of the kaolinite/hematite/goethite samples from Mali and those from colloidal soils elsewhere. Results from this study can be integrated into a database of mineral dust properties, for applications in climate modeling, remote sensing, visibility, health (medical geology), ocean fertilization, and impact on equipment.

\section{Introduction}

Globally, airborne mineral dust has the largest mass emission rate, average column mass burden, and average optical depth of all aerosol types (Satheesh and Moorthy, 2005). More than half $(\approx 62 \%)$ of the global airborne mineral dust mass is emitted in North Africa (Engelstaedter et al., 2006), with lesser fractions from Asia $(\approx 15 \%)$ and the Arabian Peninsula $(\approx 11 \%$ ) (Tanaka and Chiba, 2006). Minerals are among the largest atmospheric aerosol particles, ranging from $0.1 \mu \mathrm{m}$ to more than $100 \mu \mathrm{m}$ in diameter.

In the past only particles less than $\approx 10 \mu \mathrm{m}$ in diameter were considered to survive long-range transport in the atmosphere (Maring et al., 2003; Zender et al., 2003). However, multiple studies have shown larger mineral dust particles to have been transported over distances of hundreds to thousands of kilometers (Alastuey et al., 2005; Betzer et al., 1988; Lawrence and Neff, 2009; McTainsh et al., 1997; Neff et al., 2013; Menéndez et al., 2014). For example, quartz particles, up to $\approx 160 \mu \mathrm{m}$, ascribed to Saharan dust 
storms, were reported from deposits on La Graciosa Island (Menéndez et al., 2014), about $160 \mathrm{~km}$ off the west coast of Africa. Samples of airborne dust collected off the west African coast (Stuut et al., 2005) had mean size ranges from 8 to $42 \mu \mathrm{m}$, with particles of up to $200 \mu \mathrm{m}$ being identified. A study on Asian dust transported to Korea over a distance of $2000 \mathrm{~km}$ showed a substantial proportion of giant mineral particles, up to $60 \mu \mathrm{m}$ in diameter (Jeong et al., 2014). These particles were found to be comprised of clay aggregates as well as clay coated quartz, feldspar, and mica grains. Complex aggregates (iberulites) of up to $100 \mu \mathrm{m}$ in diameter, were postulated to have formed in the atmosphere during long-range transport of mineral dust from Saharan and Sahel to southern Spain (Díaz-Hernández and Párraga, 2008). Furthermore, these aggregates were found to be composed largely of quartz, feldspars, and carbonates, in a matrix of various clay minerals (Cuadros et al., 2015).

The mineralogy of dust from different geological domains differs from each other. How these relate to variations in optical properties influencing radiative effects, visibility impairment, and their potential health effects is not clearly understood. An interdisciplinary approach to characterizing mineral dust from different geological source regions provides important information for modeling of radiative effects and climate change (e.g., Satheesh and Moorthy, 2005), remote sensing (e.g., Ginoux et al., 2012), visibility impairment (e.g., Watson, 2002), as well as impact on solar energy production (e.g., Sayyah et al., 2014), ecosystems (e.g., Field et al., 2010), and human health (Middleton et al., 2008; Norboo et al., 1991; Wiggs et al., 2003; Fubini and Fenoglio, 2007; Ghio et al., 2014). The prime objective of this publication is to provide speciated information on mineral dust aerosol optical properties, mineralogy, chemistry, as well as particle morphology and size distribution, all required for assessments of regional and global impacts of mineral dust.

Related previous publications provided geographically limited information on mineral dust optical properties (e.g., Moosmüller et al., 2012; Müller et al., 2009; Petzold et al., 2009; Schladitz et al., 2009; Von Hoyningen-Huene et al., 2009), chemical composition, mineralogy, and particle size distribution (e.g., Al-Dousari and Al-Awadhi, 2012; Avila et al., 1997; Kahlaf et al., 1985; Kandler et al., 2007, 2009; Molinaroli, 1996). This paper expands on these previous contributions by presenting properties of a global set of resuspended dust samples applying similar sample collection, preparation, and analysis methods.

\section{Sampling and analysis}

\subsection{Sample collection and preparation}

Surface soil samples had previously been collected at more than 100 sites worldwide, of which 65 were selected for re-suspension, monitoring, and analysis (Fig. 1, Supple-

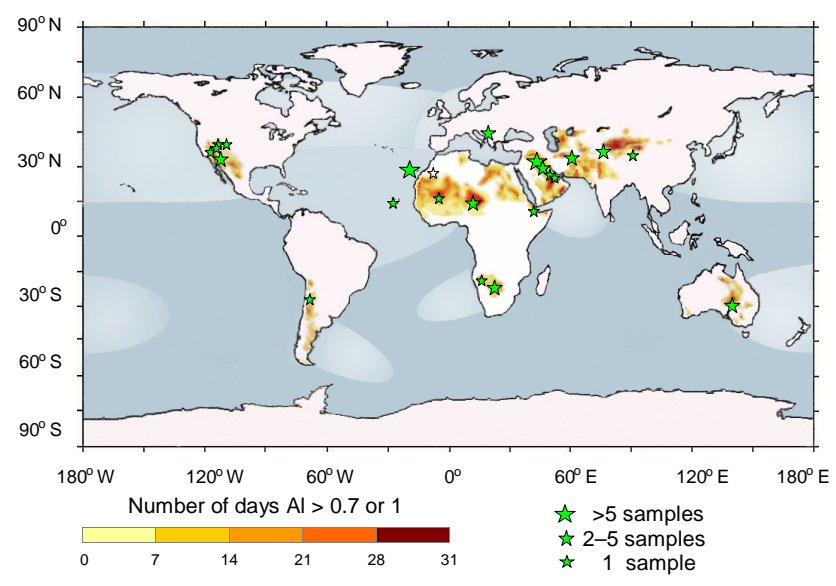

Figure 1. Surface soil sampling regions shown as green stars on a global map of dust sources as identified from Total Ozone Mapping Spectrometer (TOMS) data (Prospero et al., 2002). The size of the marker is approximately proportional to the number of samples collected in the region.

ment S1). Included are samples from the Middle East (Iraq (6), Kuwait (5), Qatar (1), United Arab Emirates (UAE) (1), Afghanistan (3), Djibouti (1)), USA (Arizona (4), California (2), Nevada (3), Colorado (1), Utah (2)), China (5), Spain (Canary Islands (8)), Morocco (1), Mali (3), Cabo Verde (1), Chad (3), Serbia (3), Australia (3), Botswana (4), Namibia (3), Chile (1) (Fig. 1), as well as one sample of hematite $\left(\mathrm{Fe}_{2} \mathrm{O}_{3}\right)$. The selected samples, of variable mineral and chemical compositions, are representative of many major dust regions. However, surface soils from dust sources in parts of North Africa, Middle East, India, Central Asia, South America, Australia, and southern Africa have either not been collected and therefore not included in the investigated sample set or, for reasons related to the samples themselves, not been analyzed in this study.

The grab soil samples collected in the field were generally sieved to $<1 \mathrm{~mm}$ to remove larger pebbles, plant material, and other unwanted debris. Where necessary, they were air-dried in the laboratory, before being labeled, catalogued, and stored in capped plastic bottles. Particle size distributions were performed on the $<600 \mu \mathrm{m}$ sieved sample sets. Subsets of these samples were sieved to $<38 \mu \mathrm{m}$ for mineral analysis by X-ray powder diffraction (XRD) and for re-suspension and subsequent chemical and scanning electron microscopic (SEM)-based analysis. Further subsets were sieved to $>75$, $<125 \mu \mathrm{m}$ for mineral mounts and investigation by optical microscopy. All samples were dry sieved, so as to retain their mineralogical and physical integrity as close as possible to the surface soils from which they were sampled. Wet sieving of samples was avoided since that would dissolve evaporite minerals such as chlorides and sulfates contained in several samples and also disaggregate clay clusters into smaller fragments, thereby creating a bias towards the finer particle sizes (Choate et al., 2006). The re-suspension of dry sieved 
samples in a chamber would approximate the mechanism for generating dust, such as particle bombardment and fragmentation of dust aggregates (Kok, 2011; Shao, 2001).

The $<38 \mu \mathrm{m}$ sieved size fraction of each sample was visually color coded by comparing to the Munsell color charts (Supplement S3.1). The Munsell system specifies the color of soils based on hue, lightness, and color purity (chroma) and has been adopted for soil research by the US Department of Agriculture. Various red or brown hues of the dusts can generally be ascribed to the presence of iron and manganese oxides and iron-bearing clay minerals in the soils.

\subsection{Petrographic assessment}

Mineral grain mounts for optical microscopy of the $>75$, $<125 \mu \mathrm{m}$ sieved soil fractions were prepared. The mineral grains were mounted in epoxy on a glass slide and ground to a thickness of approximately $30 \mu \mathrm{m}$ for transmitted light optical microscopy. Petrographic microscopy is particularly suited to the optical identification of mineral grains larger than about $10 \mu \mathrm{m}$. Mineral properties such as texture, color, pleochroism, birefringence, refractive index, and twinning were used to identify silicate minerals. Minerals readily identified in the grain mounts include quartz, various feldspars (plagioclases, orthoclase, microcline), amphiboles (hornblende), pyroxenes (augite), micas (muscovite, biotite), chlorite, carbonates, and oxides (Supplement S2.1).

\subsection{Mineral analysis by XRD}

$\mathrm{XRD}$ is the single most important nondestructive technique for characterization of minerals such as quartz, feldspars, calcite, dolomite, clay minerals, and iron oxides in fine dust. A Bruker D8 system with sample stacker and spinner was used to collect the XRD spectra, while Bruker Topas ${ }^{\circledR}$ software employing the relative intensity ratio (RIR) procedure was applied for semi-quantitative analyses of the XRD spectra of the dust samples (Rietveld, 1969; Chung, 1974; Esteve et al., 1997; Sturges et al., 1989; Caquineau et al., 1997) (Supplement S2.2).

\subsection{Particle size analysis}

Laser particle size analysis was performed on each of the soil samples. The system measures the size-class fractions of a soil or sediment sample in an aqueous suspension, based on the principle that light scatters at angles inversely proportional to, and with intensity directly proportional to, particle size (Gee and Or, 2002). The grab samples were dry sieved to $<600 \mu \mathrm{m}$ before being introduced to the laser analyzer (Micromeritics Saturn DigiSizer 5200 ${ }^{\circledR}$ ) in an aqueous medium of $0.005 \%$ surfactant (Na metaphosphate). The particles were then internally dispersed by applying ultrasonication and circulated through the path of the laser light beam. The measured size-class fractions were grouped as

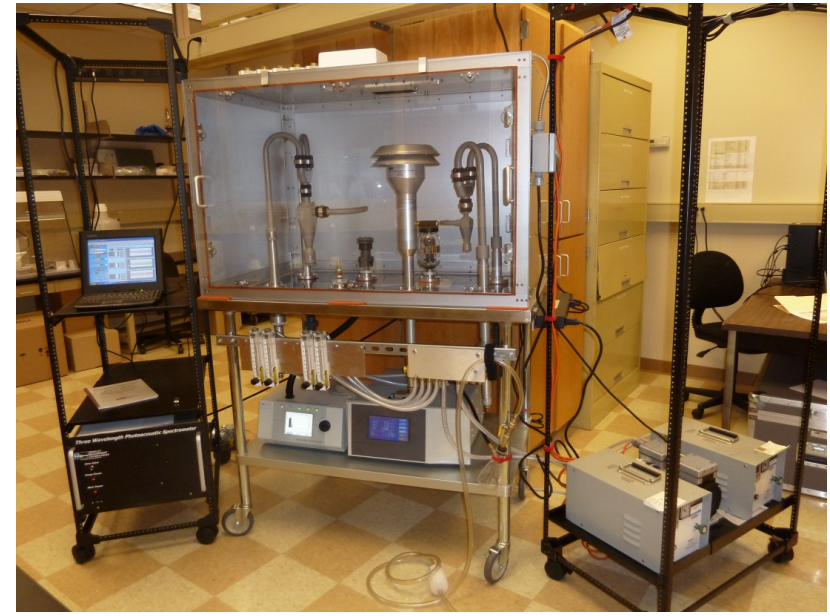

Figure 2. Integrated dust entrainment facility: three-wavelength photoacoustic instrument (DMT PASS-3) on rack to the left, resuspension chamber on trolley in the center, with a particle size analyzer and beta-attenuation gauge installed below the chamber, and an array of vacuum pumps on rack to the right.

clay $(<2 \mu \mathrm{m})$, silt $(2-62.5 \mu \mathrm{m})$, and sand $(62.5-600 \mu \mathrm{m})($ Engelbrecht et al., 2012) (Supplement S2.3).

\subsection{Dust entrainment}

A dust entrainment facility (Fig. 2) was configured with an array of instrumentation, including (i) three-wavelength photoacoustic instrument, (ii) beta attenuation gauge, (iii) aerodynamic particle size analyzer, (iv) desktop computer, and (v) PM filter samplers (http://www.dri.edu/das-laboratories/ 4185-dust-entrainment-and-characterization-facility).

A dust plume was generated by puffing the dust into the resuspension chamber with compressed air, from which particles were sampled onto filters, together with continuous optical, particulate mass concentration, and particle size measurements (Moosmüller et al., 2012). Dust measurements were focused on the size fraction associated with long-range transport, typically less than $9 \mu \mathrm{m}$ in physical diameter (Pye, 1987). All samples were screened through a $38 \mu \mathrm{m}$ poresize stainless steel sieve prior to re-suspension. The $<38 \mu \mathrm{m}$ sieved fractions served as source material from which fractions of interest; i.e., $\mathrm{PM}_{10}(\leq 10 \mu \mathrm{m}$ aerodynamic diameter) and $\mathrm{PM}_{2.5}(\leq 2.5 \mu \mathrm{m}$ aerodynamic diameter $)$ were separated. The procedure was to place about $1 \mathrm{~g}$ of the $<38 \mu \mathrm{m}$ sieved dust sample in a conical glass flask, into which a jet of filtered air was injected, transporting the dust plume into the plexiglass-fronted re-suspension chamber. From there the dust aerosol was drawn through size selective inlets, either $\mathrm{PM}_{10}$ or $\mathrm{PM}_{2.5}$, and directed to the optical, gravimetric, and particle size monitors, as well as to the four PM filter samplers.

The most important optical properties (Bergstrom et al., 2007; Chýlek and Wong, 1995; Hassan et al., 2015) for calcu- 
lating aerosol radiative impacts are scattering $\left(\beta_{\mathrm{sca}}\right)$ and absorption $\left(\beta_{\text {abs }}\right)$ coefficients, from which the extinction $\left(\beta_{\text {ext }}\right)$ coefficients are calculated, (scattering $\left(\beta_{\text {sca }}\right)+$ absorption $\left(\beta_{\text {abs }}\right)=$ extinction $\left(\beta_{\text {ext }}\right)$, and

single-scattering albedo (SSA)

$$
=\frac{\beta \mathrm{sca}}{\beta \mathrm{sca}+\beta \mathrm{abs}}=\frac{\beta \mathrm{sca}}{\beta \mathrm{ext}},
$$

The photoacoustic instrument (PA) (Arnott et al., 1999, 2000; Lewis et al., 2008) with an integrating reciprocal nephelometer for optical characterization of re-suspended mineral dusts provided scattering and absorption coefficients, from which extinction coefficient and single-scattering albedo were calculated. Real-time measurements of aerosol light absorption, due predominantly to light-absorbing minerals (e.g., hematite $\left(\mathrm{Fe}_{2} \mathrm{O}_{3}\right)$, goethite $(\mathrm{FeO}(\mathrm{OH}))$, Fe-bearing clays) in most dusts, were performed on the integrated $\mathrm{PA} /$ nephelometer. Scattering and absorption coefficients were measured on $\mathrm{PM}_{2.5}$ dust size fractions at 405,532 , and $781 \mathrm{~nm}$ wavelengths (Supplement S3.1, S3.2).

The optical coefficients have dimensions of inverse distance $\left(\mathrm{Mm}^{-1}\right)$, and it is useful to ratio them to aerosol mass concentration $\left(\mu \mathrm{g} \mathrm{m}^{-3}\right)$, yielding aerosol scattering (absorption) mass efficiencies $\left(\mathrm{m}^{2} \mathrm{~g}^{-1}\right)$. Optical mass efficiencies can be used in conjunction with modeling of atmospheric mass loadings and concentrations to calculate optical coefficients of the ambient atmosphere or, in reverse, to calculate ambient mass concentrations from optical measurements (e.g., from satellite-based optical remote sensing instruments). Such measurements are most important in the green wavelength $(500-550 \mathrm{~nm})$, where the solar spectral power density is greatest. Additional measurements covering the shortwave radiatively important spectrum are significant for aerosol light absorption because of spectrally varying absorption of some mineral dust particles (Moosmüller et al., 2009).

\subsection{Filter analysis}

Teflon ${ }^{\circledR}$ membrane and quartz fiber filters were conditioned and weighed prior to and after sampling for subsequent mass and chemical composition determinations of the dust samples.

In the course of this study, about 130 Teflon ${ }^{\circledR}$ filters were analyzed by energy dispersive X-ray fluorescence spectrometry (EDXRF) (Watson et al., 1999; US EPA, 1999) for chemical elements, including magnesium $(\mathrm{Mg})$, aluminum $(\mathrm{Al})$, silicon $(\mathrm{Si})$, potassium $(\mathrm{K})$, calcium $(\mathrm{Ca})$, titanium $(\mathrm{Ti})$, and iron $(\mathrm{Fe})$. After completion and validation of the EDXRF results, the same 130 Teflon ${ }^{\circledR}$ filters were dissolved in nitric/hydrochloric acid, and the solutions analyzed by inductively coupled plasma mass spectrometry (ICP-MS) for 12 trace metals: antimony $(\mathrm{Sb})$, arsenic (As), beryllium (Be), cadmium $(\mathrm{Cd})$, chromium $(\mathrm{Cr})$, lead $(\mathrm{Pb})$, manganese $(\mathrm{Mn})$, nickel $(\mathrm{Ni})$, vanadium $(\mathrm{V})$, zinc $(\mathrm{Zn})$, mercury $(\mathrm{Hg})$, and strontium ( $\mathrm{Sr}$ ).

Water extractions were performed on one half of each of the 130 quartz fiber filters. Aliquots of the extractions were analyzed by ion chromatography (IC) (Chow and Watson, 1999) for water soluble anions: sulfate $\left(\mathrm{SO}_{4}^{2-}\right)$, nitrate $\left(\mathrm{NO}_{3}^{-}\right)$, chloride $\left(\mathrm{Cl}^{-}\right)$, phosphate $\left(\mathrm{PO}_{4}^{3-}\right)$, and the ammonium $\left(\mathrm{NH}_{4}^{+}\right)$cation. Further aliquots of the extractions were analyzed by inductively coupled plasma optical emission spectrometry (ICP-OES) for water-soluble cations: sodium $\left(\mathrm{Na}^{+}\right)$, potassium $\left(\mathrm{K}^{+}\right)$, calcium $\left(\mathrm{Ca}^{2+}\right)$, and magnesium $\left(\mathrm{Mg}^{2+}\right)$.

Chemical abundances for $\mathrm{PM}_{10}$ and $\mathrm{PM}_{2.5}$ size fractions were combined into normative mineral abundances and also presented graphically. Scatter plots of selected major chemical species were compiled and elemental ratios tabulated. The relationships between the SSA and the major chemical components are graphically presented.

\subsection{SEM-based individual particle analysis}

SEM-based individual particle analysis was performed on $65 \mathrm{PM}_{2.5}$ filters selected from approximately 130 sampled Nuclepore ${ }^{\circledR}$ filters. The samples were analyzed by two complementary methods, the first being computercontrolled scanning electron microscopy (CCSEM) using automated particle analysis software and the second being highresolution manual SEM examination to document particle imagery.

CCSEM was performed using a combination of backscattered electron and secondary electron (SE) imagery along with energy dispersive spectroscopy (EDS). A large number (often more than 1000) of individual particles were analyzed for chemical composition, particle size, and shape by this method. The measurements on the particles are grouped into "bins" by chemical composition and particle size. The CCSEM results were routinely grouped into 29 chemical categories or "bins". Following on preliminary statistical evaluation of the chemical data and a priori information of the mineralogical composition (from XRD, optical microscopy, and particle morphology) the number of chemical "bins" were reduced to 15. Mineral names were assigned to each of the chemical categories, e.g., Si-rich category as quartz, Ca-rich category as calcite, $\mathrm{Ca}, \mathrm{Mg}$ category as dolomite, $\mathrm{Ca}, \mathrm{S}$ category as gypsum, $\mathrm{Fe}$-rich category as iron oxides, $\mathrm{Ca}, \mathrm{Al}, \mathrm{Mg}$ category as clay, $\mathrm{Ca}, \mathrm{Al}, \mathrm{Si}$ category as $\mathrm{Ca}$ feldspar, $\mathrm{Na}, \mathrm{Al}$, $\mathrm{Si}$ category as $\mathrm{Na}$ feldspar, $\mathrm{K}, \mathrm{Al}$, Si category as K feldspar. Summary plots of the inferred mineral compositions were compiled. Individual particle morphology, including aspect rations, was measured by CCSEM. Although labor intensive, manual SEM analysis allows for collection of superiorquality, high-resolution SE images. This technique further allows for the study of particle shape, surface coatings, and chemical composition. Approximately five secondary elec- 
tron images (SEIs) with EDS for each of the $65 \mathrm{PM}_{2.5}$ filter samples were collected in this fashion.

\section{Results}

\subsection{Sample descriptions}

All results are compiled in the Supplement to this paper, with the sampling sites listed in Supplement S1, mineralogy by optical microscopy in Supplement S2.1, mineralogy by XRD in Supplement S2.2, and particle size fractions (volume \%) distributions of the $<600 \mu \mathrm{m}$ sieved particle fractions in Supplement S2.3. Munsell color indices and SSA are listed in Supplement S3.1. Also shown on each sample sheet in Supplement S3.2 are beta attenuation gauge mass measurements for $\mathrm{PM}_{10}$ and $\mathrm{PM}_{2.5}$ collected in parallel with the absorption and scattering coefficients, particle size distributions and statistics, mass measurements for $\mathrm{PM}_{10}$ and $\mathrm{PM}_{2.5}$ on Teflon filters, and $\mathrm{PM}_{2.5} / \mathrm{PM}_{10}$ mass ratios, collected for each sample. Statistics on the SEM measured aspect ratios are tabulated on the individual sheets. The chemical results of the $\mathrm{PM}_{10}$ and $\mathrm{PM}_{2.5}$ dust samples on filters are tabulated in Supplement S4.1, normative mineral calculations from the chemical results are tabulated in Supplement S4.2, and plots therefrom are shown in Supplement S4.3. Scatter plots of the major chemical species expressed as oxides are shown in Supplement S4.4, the relationships between chemical compositions and SSA in Supplement S4.5, and ratios of selected major chemical components tabulated in Supplement S4.6. The SEM-based individual particle results collected on $\mathrm{PM}_{2.5}$ Nuclepore ${ }^{\circledR}$ filters are shown in Supplement S5.1-S5.4. The individual particle results tabulated in 29 chemical bins are given in Supplement S5.1, their mineral interpretations in 15 mineral bins in Supplement S5.2 with associated plots of the last mentioned in Supplement S5.3. Statistics on the SEM-based aspect ratios measured on individual particles are tabulated in Supplement S5.4 and shown in Supplement S3.2. Supplement S5.5 shows the EDS spectra and associated SEIs of selected individual particles from each re-suspended dust sample.

Descriptions of samples from each geographic region are summarized below.

\subsubsection{Southwestern USA - Owens Lake, CA (S1019)}

The dried lakebed contains minerals washed in from the adjoining Sierra and Inyo mountains by the Owens River as well as small amounts of evaporite deposits. Since about 1926 the lake remained dry as a result of overuse of its water for agriculture and human consumption by the city of Los Angeles (Wilkerson et al., 2007). The coarser sand and silt fractions contain plagioclase, calcite, quartz, biotite mica, and hornblende, with halite, kaolinite, and trona in the finer fractions. These minerals are abundant in local aerosols generated during dust events, thereby creating a ma- jor health issue along the Owens Valley and poor visibility at the nearby China Lake Naval Air Station (Reheis, 1997; Wilkerson et al., 2007). This resulted in ongoing mitigation steps to contain alkaline dust being blown off the playa. (www.ladwp.com/OwensLake).

\subsubsection{Southwestern USA - Black Rock, NV (S1045)}

The Black Rock playa about $150 \mathrm{~km}$ north of Reno is known for its very flat lakebed, with approximately $1 \mathrm{~m}$ altitude variation over an area of $300 \mathrm{~km}^{2}$. The lakebed is normally wet during the winter and spring from water and fine sediment transported from the Quinn and Mud Meadows Creek rivers. During the other seasons the dry playa is used for multiple recreational activities, including the annual Burning Man (http://www.burningman.com/) event, for a week each in August every year. As a result, the dry lakebed is continually being disturbed by human and vehicular traffic, creating intense dust palls during windy conditions (Adams and Sada, 2010). The surface sediment of the playa is fine silt and clay, illite, with small amounts of calcite, quartz, halite, kaolinite, feldspars, hornblende, and sepiolite.

\subsubsection{Southwestern USA - NW Reno, NV (S1052, S1053)}

Two sedimentary samples were collected along the Peavine mountain foothills in northwestern Reno. The first (S1052) is an off-white diatomaceous lakebed deposit (Smedman, 1969), containing diatoms (Fig. 3), plagioclase, quartz, and lesser amounts of clay (kaolinite, sepiolite, illite, montmorillonite), stilbite, and biotite. The second (S1053) is a yellowish brown soil, the color being ascribed to iron oxides (goethite), in addition containing quartz and plagioclase and smaller amounts of hornblende, biotite, muscovite, and clays (palygorskite, montmorillonite, kaolinite).

\subsubsection{Southwestern USA - Carbondale, CA (S1065)}

Carbondale Red Clay is a commercially available fireclay, considered to be the equivalent of Martian dust (White et al., 1997). The material is composed of very finely ground quartz and kaolinite with a high percentage of hematite (Fig. 4).

\subsubsection{Southwestern USA - Yuma, AZ (S3003, S3004)}

The two grab samples were collected from improved artillery firing pads at the Yuma Proving Ground (YPG) (Gillies et al., 2007). The samples contain major amounts of quartz and calcite, together with lesser amounts of dolomite, mica (biotite, muscovite), feldspars (plagioclase, microcline), hornblende, gypsum, and clays. To compact the soil and contain the dust during the gun firing activities, brines containing potassium sulfate and other salts were sprayed onto the firing pads. Trace amounts of copper, bismuth, and lead from the spent 

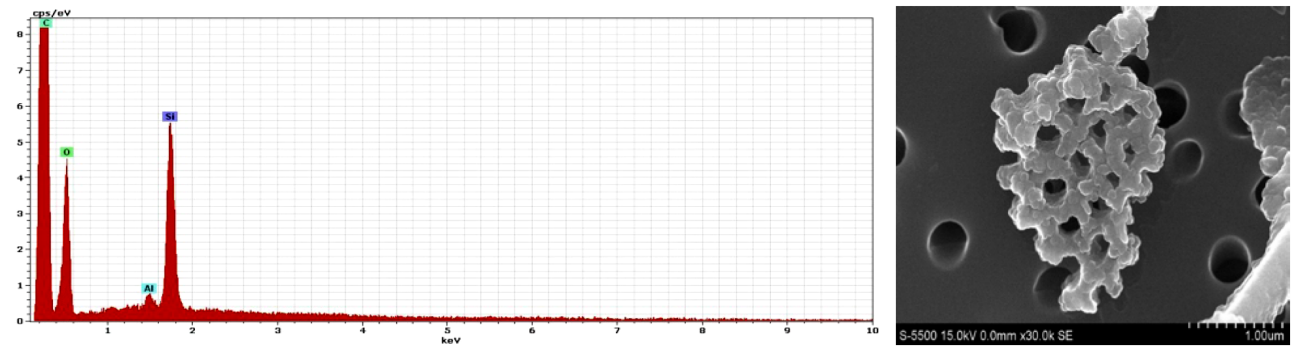

Figure 3. SEM-based EDS spectrum and SEI of a particle from re-suspended sample S1052 from Reno, Nevada: a fragment of a diatom containing a major component of silicon $(\mathrm{Si})$, with trace amounts of aluminum (Al) pointing to a silica particle (amorphous?) with a minor amount (coating?) of clay, and possibly kaolinite.

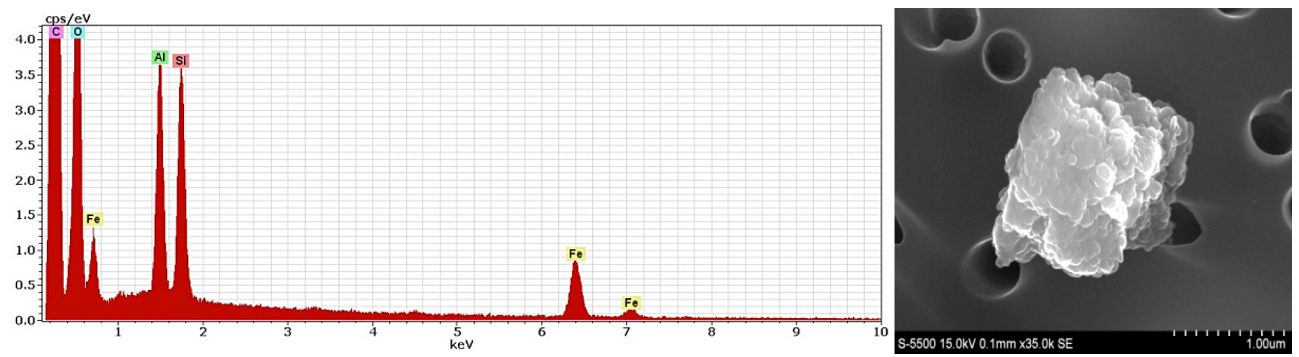

Figure 4. SEM-based EDS spectrum and SEI of a particle from re-suspended sample S1065 (red clay) from Carbondale, California. Composite particle containing major components of aluminum (Al) and silicon ( $\mathrm{Si}$ ), possibly the clay mineral kaolinite, as well as iron (Fe) in hematite or goethite.

ordnance are present in the finer dust fractions (Engelbrecht et al., 2012).

\subsubsection{Southwestern USA - Yuma, AZ (S3008)}

This surface soil sample was collected during a field campaign measuring dust emissions, created by rotary-winged aircraft (Gillies et al., 2010). The sample contains rounded quartz grains together with calcite, feldspars (plagioclase, microcline), and mica (biotite, muscovite) and small amounts of hornblende, clay (kaolinite), dolomite, gypsum, and apatite (Engelbrecht et al., 2012).

\subsubsection{Southwestern USA - Ft. Carson, CO (S3011)}

Fort Carson is located in central Colorado at the foot of the Rocky Mountains and to the south of Colorado Springs. The area is underlain largely by fluvial and alluvial clays, silts, and sands. The surface soil sample was collected from an unpaved road on the military base. It contains major amounts of quartz and plagioclase, with lesser amounts of biotite, potassium feldspars, calcite, hornblende, muscovite, dolomite, gypsum, and clays (Engelbrecht et al., 2012).

\subsubsection{Southwestern USA - Dugway, UT (S3016, S3017)}

The two samples from Utah are similar to each other, both collected along built-up dirt roads on the military base. The road gravel material had been excavated from a local quarry.
Both samples contain major amounts of quartz and calcite (Fig. 5) and lesser amounts of dolomite, aragonite, plagioclase, with traces of biotite, muscovite, illite, and orthoclase.

\subsubsection{Middle East - Djibouti (S2001)}

Djibouti lies in the Afar triangle, which is part of the African continental rift zone, underlain by basaltic lava flows and associated sediments. Minerals in the screened dust sample including pyroxenes, amphiboles, olivines, plagioclases, ilmenites, and magnetites $\left(\mathrm{Fe}_{3} \mathrm{O}_{4}\right)$ are also contained by the surrounding rock outcrops. The nearly $10 \%$ calcite in the sample could be from raised coral reefs in the surrounding Red Sea (Engelbrecht et al., 2009b, 2008).

\subsubsection{Middle East - Afghanistan (S2002, S2003, S2016)}

The first two sites are in northeastern Afghanistan in the mountainous region close to the Pakistan border, while the third is in the Helmand province. Dust storms originating in the southwestern part of the country move in a counterclockwise direction, funneling wind-blown dust toward Kabul, Bagram, and Khowst. The Bagram site is underlain by loess (wind deposited silt), sand, and clay and the Khowst site by alluvium containing gravel, sand, silt, and clay. These last mentioned two samples from Afghanistan are mineralogically similar, both containing major amounts 

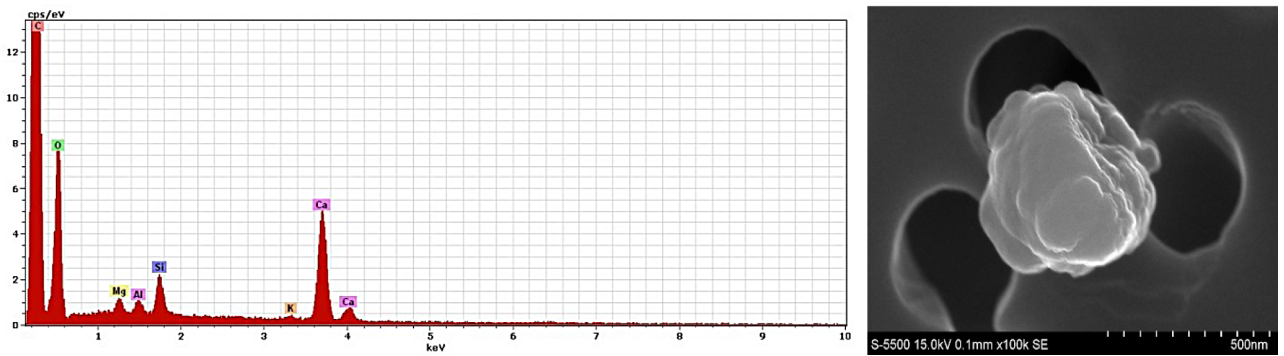

Figure 5. SEM-based EDS spectrum and SEI of a particle from re-suspended sample S3017, from Dugway, Utah. Particle with major amount of calcium $(\mathrm{Ca})$ from calcite, with aluminum $(\mathrm{Al})$, silicon $(\mathrm{Si})$, and magnesium $(\mathrm{Mg})$ and potassium $(\mathrm{K})$; there is evidence of a coating of clay and possibly illite.
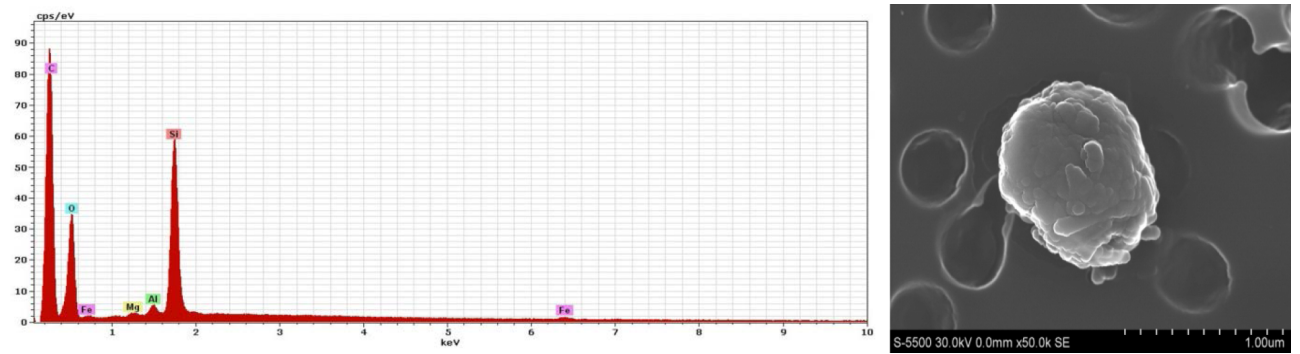

Figure 6. SEM-based EDS spectrum and SEI of a particle from re-suspended sample S2016 from Camp Leatherneck, Helmand Province, Afghanistan. Well-rounded grain of quartz (containing $\mathrm{Si}$ ) with coating of finger-shaped clay mineral containing aluminum (Al), magnesium $(\mathrm{Mg})$, iron $(\mathrm{Fe})$, and possibly palygorskite.

of quartz, calcite, and clays (kaolinite, illite, palygorskite), with smaller amounts of feldspar, mica (biotite, muscovite), chlorite, and amphibole (Engelbrecht et al., 2009b, 2008). The sample from Helmand Province (S2016) contains largely quartz (Fig. 6) and calcite with small amounts of clays, gypsum, and silicates.

\subsubsection{Middle East - Qatar (S2004) and UAE (S2005)}

Qatar and UAE are impacted largely by windblown dust transported from the Arabian Peninsula, Iraq, and Kuwait. Samples from both sites contain large amounts of calcite, dolomite, quartz, and feldspar and lesser amounts of chlorite, clay minerals, gypsum, and anhydrite. The Qatar sample also contains small amounts of hornblende and ilmenite, probably transported from weathered volcanics in Saudi Arabia to the west of the sampling site (Engelbrecht et al., 2009b, 2008).

\subsubsection{Middle East - Iraq (S2006, S2007, S2008, S2009, S2010, S2011)}

Satellite imagery shows dust storms, blowing across Iraq and Kuwait from salt flats and wadis along the border with Turkey and Syria (Engelbrecht et al., 2009b), being major sources of windblown dust in the region. The Baghdad site, as well as the three sites further north and close to the Tigris River (Taji, Balad, and Tikrit), contains major amounts of quartz, calcite, and feldspar, plus smaller amounts of gyp- sum, micas, and clays. The Tallil sample, collected further to the south and close to the Tigris-Euphrates river confluence, also contains the evaporite mineral gypsum. This sampling site is underlain by poorly drained river-basin soils, and the gypsum could be wind-entrained from the gypsiferous desert immediately to the southwest of Tallil. Al Asad, closer to the Euphrates River and $200 \mathrm{~km}$ to the west of Baghdad, differs from the other five Iraqi sites in that its soil contains largely dolomite, with small amounts of gypsum, and quartz. This region is underlain by soils containing gypsum, limestone, and sandstone (Buringh, 1960). XRD analysis of the sieved dust samples confirms that the limestone in this region is largely dolomite, instead of calcite identified at the other five Iraq sampling sites (Engelbrecht et al., 2009b, 2008).

\subsubsection{Middle East - Kuwait (S2012, S2013, S2014, S2015, S2017)}

The samples from Kuwait contain higher fractions of silt than those from adjacent Iraq, with major amounts of quartz and calcite. Samples from all five sites also contain a significant amount of feldspar, both plagioclase and potassium feldspar (Fig. 7) as well as micas (muscovite, biotite) and clay minerals. Previous studies on fallout dust in Kuwait (Al-Awadhi, 2005) identified the clay minerals as palygorskite, together with illite-montmorillonite and a smaller proportion of kaolinite. Al-Awadi (2005) and Kahlaf et al. (1985) suggest that 

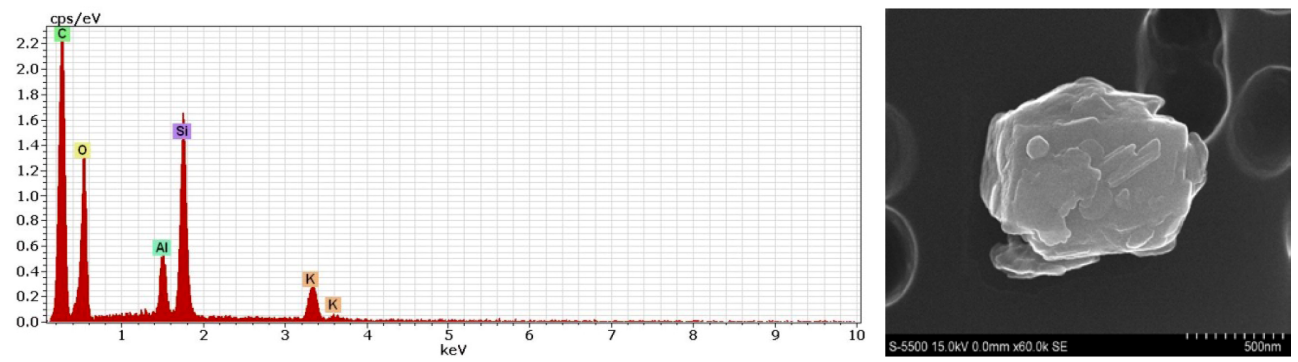

Figure 7. SEM-based EDS spectrum and SEI of a particle from re-suspended sample S2017 from Kuwait. Orthoclase identified from its silicon $(\mathrm{Si})$, aluminum $(\mathrm{Al})$, and potassium $(\mathrm{K})$ content as well as crystal morphology. Finger-shaped particles on the feldspar surface may be palygorskite.

most of the dust in Kuwait to have been transported from the dry Mesopotamian floodplain in southern Iraq and other parts of the Arabian peninsula (Engelbrecht et al., 2009b, 2008).

\subsubsection{Northern Africa - Canary Islands (Las Canarias) (Lanzarote (1005, S1006, S1007, S1008), Gran Canaria (S1027), Fuerteventura (S1033, S1034, S1035))}

The Canary Island archipelago lies along the westward pathway of Saharan dust blowing off the west coast of North Africa, the islands being impacted by severe dust events in that region (Alastuey et al., 2005; Bergametti et al., 1989; Criado and Dorta, 2003; Gelado-Caballero et al., 2005; Maring et al., 2000; Menéndez et al., 2009; Pérez-Marrero et al., 2002; Viana et al., 2002; Kandler et al., 2007; Engelbrecht et al., 2014; Coudé-Gaussen et al., 1987; Mizota and Matsuhisa, 1995). It was shown that fractions of transported Saharan dust had been deposited on the islands, contributing to the formation of local soils (Jahn and Stahr, 1996; Menéndez et al., 2014, 2007; Mizota and Matsuhisa, 1995; Muhs et al., 2010; von Suchodoletz et al., 2013, 2009; Zarei, 1989; Williamson et al., 2004; Moreno et al., 2001). It can be safely assumed that samples of soils collected on these islands contain Saharan dust in variable proportions. Two samples from Fuerteventura are from dust traps in lava flows, on the eastern side of the island, approximately $100 \mathrm{~km}$ off the coast of Morocco. The sieved dust samples from the Canary Islands generally contain quartz as the major component, with minor amounts of calcite, feldspars, amphibole, pyroxenes, micas, clays, iron oxides, and volcanic glass.

\subsubsection{Northern Africa - Cabo Verde (S1013)}

The Il de Sal Island is part of the Cabo Verde archipelago, approximately $700 \mathrm{~km}$ off the west coast of Africa, and considered to be within the Sahel geographic zone. As with the Canary Islands, the Cabo Verde islands are impacted by dust blowing off the west coast of Africa. The soil sample collected on the northern side of Sal Island is assumed to contain some trapped Sahara and Sahel dust. The sample contains plagioclase and pyroxene in the coarse fraction, possibly from local weathered volcanic rocks, together with quartz, illite clay, calcite, carbonate apatite, halite, and kaolinite in the fine fraction. The carbonate apatite (francolite) (Fig. 8) is possibly of local biogenetic origin.

\subsubsection{Northern Africa - Morocco (S1025)}

Morocco is considered a major source of dust, blowing across the Mediterranean into Europe. Several studies were performed on airborne mineral dust from this region, some as part of the Sahara Mineral Dust Experiment (SAMUM) (Heintzenberg, 2009; Kandler et al., 2009; Schladitz et al., 2009; Müller et al., 2009; Petzold et al., 2009; Von Hoyningen-Huene et al., 2009; Scheuvens et al., 2013; Molinaroli, 1996; Molinaroli et al., 1993; Blanco et al., 2003; Avila et al., 1997; Jahn and Stahr, 1996).

The major minerals in this sample are quartz and illite, with smaller amounts of calcite, feldspars (plagioclase, orthoclase), hornblende, dolomite palygorskite (Fig. 9), and kaolinite.

\subsubsection{Northern Africa - Mali (S1009, S1010, S1011)}

The three grab samples were collected in a field approximately $5 \mathrm{~km}$ to the northwest of Bamako in Mali, all within $200 \mathrm{~m}$ of each other. The samples are from soils immediately to the south of the Sahel, the latter being defined as that zone adjoining the southern Sahara, which receives on average between $\sim 200$ and $\sim 600 \mathrm{~mm}$ rainfall per year. The samples are from within a tropical region where lateritic soils are developed, containing high amounts of hematite, goethite, and kaolinite (Fig. 10) (Roquin et al., 1989, 1990).

It was shown (Oldfield et al., 2014) that the magnetic properties of dusts and their hematite/goethite contents could be applied to distinguishing dust sources from North Africa impacting the Caribbean region. Moosmüller et al. (2012) showed that the optical properties such as SSA were controlled by the $\mathrm{Fe}$ content of airborne dust. Roquin et al. (1989) were able to correlate the mineralogical and chem- 

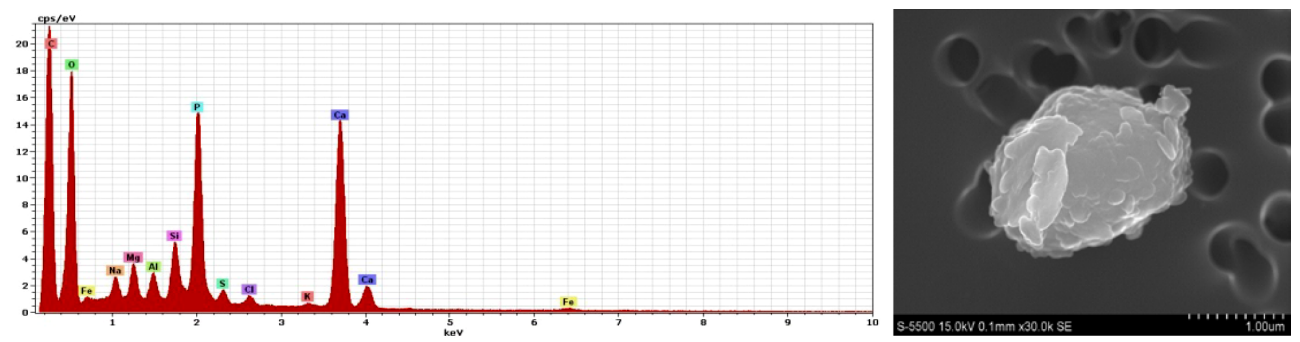

Figure 8. SEM-based EDS spectrum and SEI of a particle from re-suspended sample S1013 from Cabo Verde Islands. Particle of apatite $\left(\mathrm{Ca}_{5}\left(\mathrm{PO}_{4}\right)_{3}(\mathrm{OH})\right)$, identified from major components of phosphorous $(\mathrm{P})$ and calcium $(\mathrm{Ca})$. Small amounts of silicon (Si), aluminum $(\mathrm{Al})$, and magnesium $(\mathrm{Mg})$ can be attributed to a coating of clay. Small amounts of sulfur (S), sodium (Na), and chlorine (Cl) can be attributed to evaporites such as gypsum and halite attached to the particle.
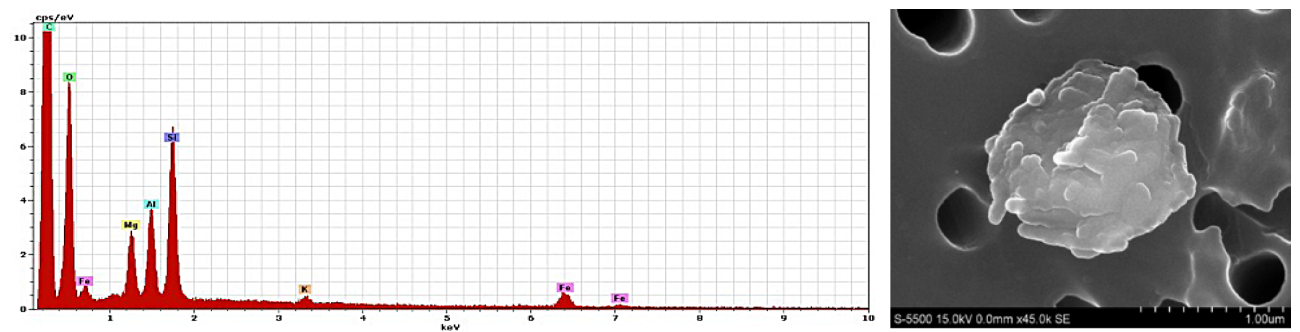

Figure 9. SEM-based EDS spectrum and SEI of a particle from re-suspended sample S1025 from Iriki, Morocco. From the relative intensities of the silicon ( $\mathrm{Si})$, aluminum ( $\mathrm{Al})$, magnesium, potassium $(\mathrm{K})$, and iron $(\mathrm{Fe})$ spectral peaks as well as the morphology shown by the SEI, it is concluded that the particle is a cluster illite (platy) and palygorskite (finger shaped).

ical information from Dagadamou region in southern Mali with the SPOT satellite imagery.

\subsubsection{Northern Africa - Chad (S1049, S1050, S1051)}

The three dry lakebed deposits were collected from the Bodélé depression in the southern Sahara region of North Africa. Bodélé is considered the largest single source of global dust (Chappell et al., 2008; Goudie and Middleton, 2001; Tegen et al., 2006; Todd et al., 2007; Washington and Todd, 2005; Middleton and Goudie, 2001), contributing to the fertilization of the Atlantic Ocean and land as far as the Amazon basin (Ben-Ami et al., 2010; Koren et al., 2006; Chadwick et al., 1999; Formenti et al., 2001; Bristow et al., 2010).

The samples contain largely amorphous silica (diatoms) (Fig. 11), quartz, and calcite with small amounts of plagioclase, potassium feldspar, kaolinite, illite, and halite.

\subsubsection{China - Northwest (S1014, S1016, S1017, S1018)}

The four samples are from far northwestern China, two (S1017, S1018) being from a locality referred to as Daemon City, named after the unusual wind eroded sandstone formations. The two samples are composed of major amounts of quartz and calcite, with plagioclase, kaolinite, mica (biotite, muscovite), and montmorillonite. The two samples further north (S1014, S1016) from the Daemon City area contain quartz and biotite, with lesser amounts of plagioclase, calcite (Fig. 12), hornblende, kaolinite, illite, sepiolite, and halite.

\subsubsection{China - Loess Plateau (S1055)}

This region in China contains the greatest thickness of loess in the world. It is an un-stratified silt deposit formed by windblown fluvioglacial deposits related to the geologically recent ice ages (Derbyshire et al., 1998; Kohfeld and Harrison, 2003; Sun et al., 2000; Lewis et al., 1984). This silt sample contains quartz with smaller amounts of calcite, plagioclase, potassium feldspar, biotite, hornblende, clay (kaolinite, illite), and mica (muscovite, biotite).

\subsubsection{Southern Africa - Botswana (S1038, S1039, S1040, S1041)}

The samples are from the dry lakebed of Makgadikgadi Pan in central Botswana. The samples contain largely calcite, quartz, the evaporate minerals trona and halite, and smaller amounts of sepiolite, illite, dolomite, plagioclase, orthoclase, muscovite, hornblende, and dolomite. During the dry winter months, the Makgadikgadi Pan is a major source of dust in southern Africa. 

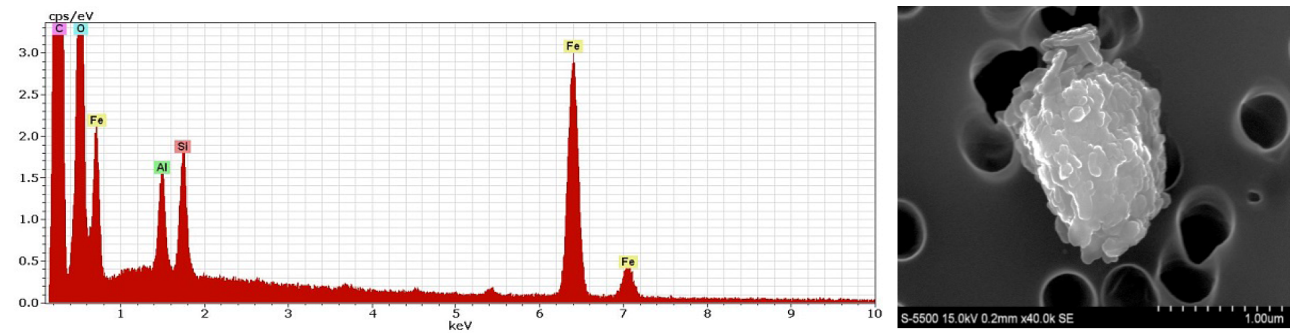

Figure 10. SEM-based EDS spectrum and SEI of a particle from re-suspended sample S1009 from Bamako, Mali. Composite grain composed of silicon ( $\mathrm{Si}$ ) and aluminum (Al) components of a clay mineral and possibly kaolinite with lesser amounts of palygorskite (finger shaped) and illite, together with iron $(\mathrm{Fe})$ in hematite or goethite.
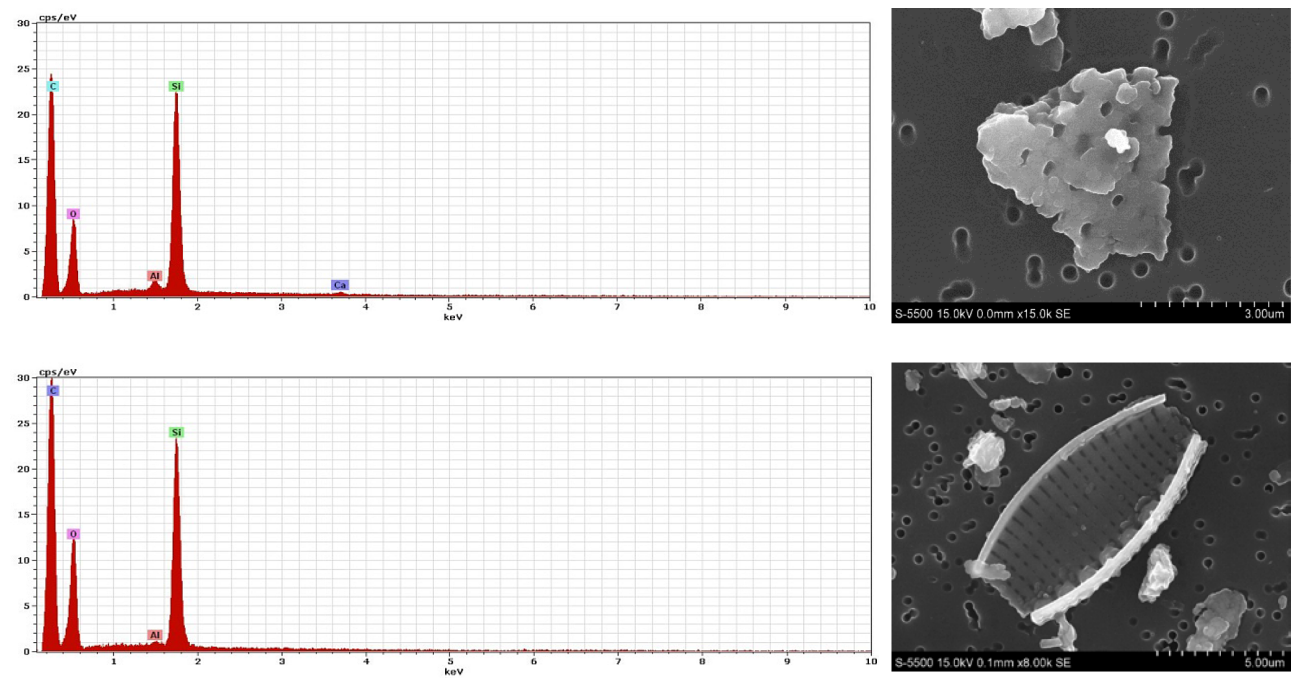

Figure 11. SEM-based EDS spectra and SEI's of particles from re-suspended samples S1049 (above) and S1051 (below) from the Bodélé region of Chad. Two examples of diatom fragments, the particles contain largely silicon ( $\mathrm{Si})$, evidence of amorphous silica or quartz $\left(\mathrm{SiO}{ }_{2}\right)$, with small amounts of aluminum (Al) from a clay mineral coating and possibly kaolinite and trace of calcium (Ca), possibly of calcite.

\subsubsection{Southern Africa - Namibia (S1022, S1023, S1024)}

Three soil samples were collected along the southern and western edge of Etosha Pan in northern Namibia. They all contain major amounts of the evaporate minerals halite, thenardite, and calcite, with sepiolite and small amounts of dolomite, plagioclase, muscovite, and amphibole (Buch and Rose, 1996). Etosha Pan, especially during the dry winter season, is a major source of dust in Namibia, exacerbated by disturbance of the lakebed being from the passage of large herds of game.

\subsubsection{South America - Chile (S1042)}

The sample was collected at the Yungay (Rock Garden) site in the Atacama Desert of Chile, considered to be one of the most arid regions of the world (McKay et al., 2003), also described as Mars-like (Navarro-González et al., 2003). The sample contains quartz as its main constituent, together with clay (illite, montmorillonite), gypsum, anhydrite, plagioclase, calcite, orthoclase, biotite, and amphibole.

\subsubsection{South Australia (1056, S1057, S1058)}

The three samples are from riverbed or lakebed deposits in the Lake Eyre and Lake Frome regions of South Australia (Marx et al., 2009; McGowan and Clark, 2008; Moreno et al., 2009), considered to be a major source of dust in the southern hemisphere, being deposited on the snow as far as the New Zealand Alps (McGowan et al., 2005; Marx et al., 2009). Evidence of dust from this region was also found in East Antarctica (Revel-Rolland et al., 2006). The samples are composed largely of quartz grains (Fig. 13) coated with clays, together with small particles of clay minerals (illite, kaolinite, palygorskite), gypsum, calcite, feldspar (plagioclase, orthoclase), and dolomite. 


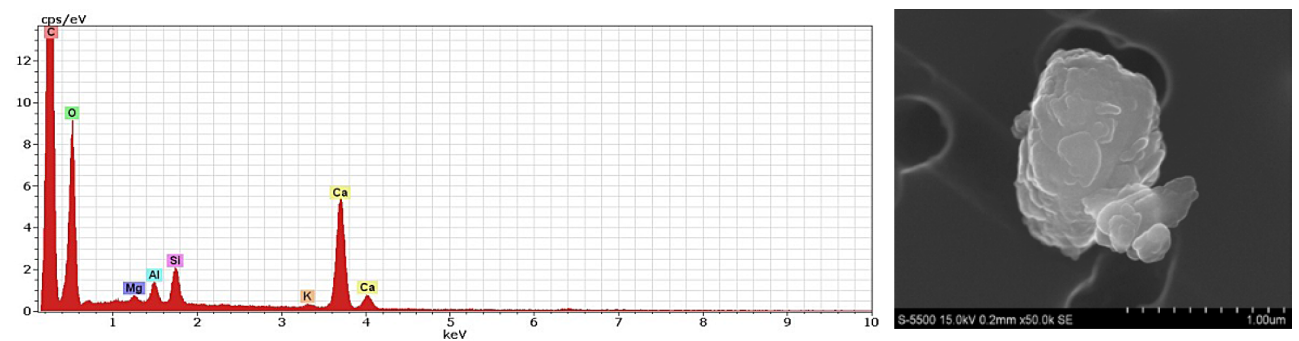

Figure 12. SEM-based EDS spectrum and SEI of a particle from re-suspended sample S1014 from northwestern China. Composite particle of calcite as seen from the high calcium (Ca) content together with a clay mineral (coating?) and possibly illite as is evident from the silicon $(\mathrm{Si})$, aluminum $(\mathrm{Al})$, magnesium $(\mathrm{Mg})$, and potassium $(\mathrm{K})$ contents.
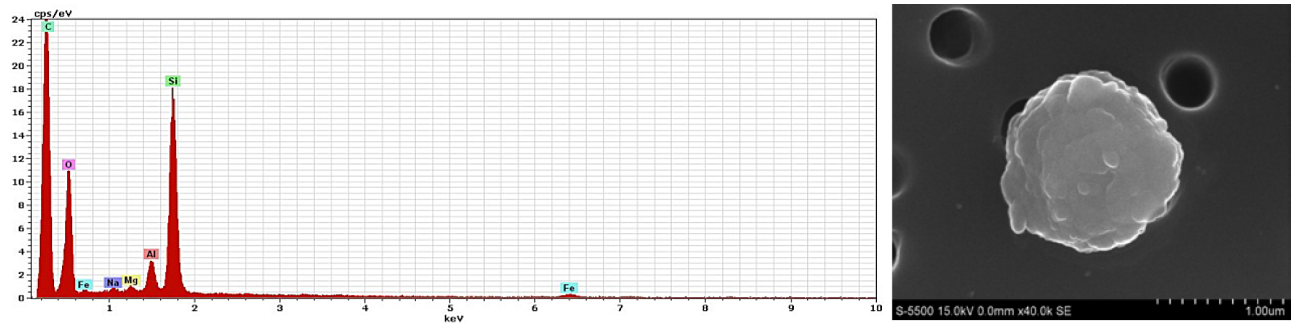

Figure 13. SEM-based EDS spectrum and SEI of a particle from re-suspended sample S1057 from Lake Eyre, Australia. Round quartz particle as evident from its silicon ( $\mathrm{Si}$ ) content, with small amounts of aluminum (Al), magnesium $(\mathrm{Mg})$, and iron (Fe) from clay (coating) and possibly illite or montmorillonite.

\subsubsection{Europe - Serbia (S1060, S1062, S1064)}

The loess samples were collected along the Danube valley in Serbia, representing loosely bound wind-blown silt deposits, related to the ice periods of the recent geological past (Marković et al., 2009, 2011). The three samples are similar, being composed mainly of rounded particles of quartz (Fig. 14), with muscovite, biotite, clay (illite, kaolinite, montmorillonite), plagioclase, dolomite, and calcite.

\subsection{Discussion}

\subsubsection{Particle size analysis}

Particle size analysis on the $<600 \mu \mathrm{m}$ sieved samples are tabulated in Supplement S2.3.

From field and laboratory measurements on dust from the western USA, Engelbrecht et al. (2012) found dust emissions to be in part dependant on the particle size distributions of the soils being disturbed. Surface soils with silt contents greater than approximately $50 \%$ and less than about $10 \%$ clay had the greatest likelihood of being sources of substantial dust emissions. On the USGS soils ternary plot (Fig. 15), soils with the greatest potential to generate dust when disturbed are those that plot in the bottom one-third of the "silt loam" field. Included are two previously characterized dust sources from Yakima Test Center (Engelbrecht et al., 2012), three from the Bodélé Depression (S1049-S1051) (Washington and Todd, 2005; Koren et al., 2006), three loess samples from the Danube River valley (S1060, S1062, S1064) (Marković et al., 2011, 2009), one sample from Kuwait (S2017) (AlDousari and Al-Awadhi, 2012; Draxler et al., 2001; Kahlaf et al., 1985), and two loess samples from China (S1017, S1055) (Burbank and Jijun, 1985; Derbyshire et al., 1998). It also includes four silt samples collected on Fuerteventura (S1033, S1034), Lanzarote (S1007), and Gran Canaria (S1027) in the Las Canarias archipelago, assumed to consist largely of dust from the western Sahara (Menéndez et al., 2014), as well as one diatomaceous silt sample from Reno, USA (S1052). This particle size criterion provides an important measure for whether a site or region has the potential to be a significant dust source.

Optical properties such as SSA are also dependent on the particle size distributions (van Staveren et al., 1991; Moosmüller and Arnott, 2009) as well as particle shape (Alexander et al., 2013) and mineralogy (Moosmüller et al., 2012). For this project we measured scattering and absorption coefficients for $\mathrm{PM}_{2.5}$, thereby confining the particle size distributions.

\subsubsection{Chemical and mineralogical interrelationships}

Dust samples are composed of mineral mixtures in variable proportions, either individual mineral grains, intergrowths, coatings on other particles, or composite mineral clusters. Their chemical compositions can in many instances be related to their mineral constituents, as verified by optical microscopy, XRD, and SEM-based individual particle analysis. 

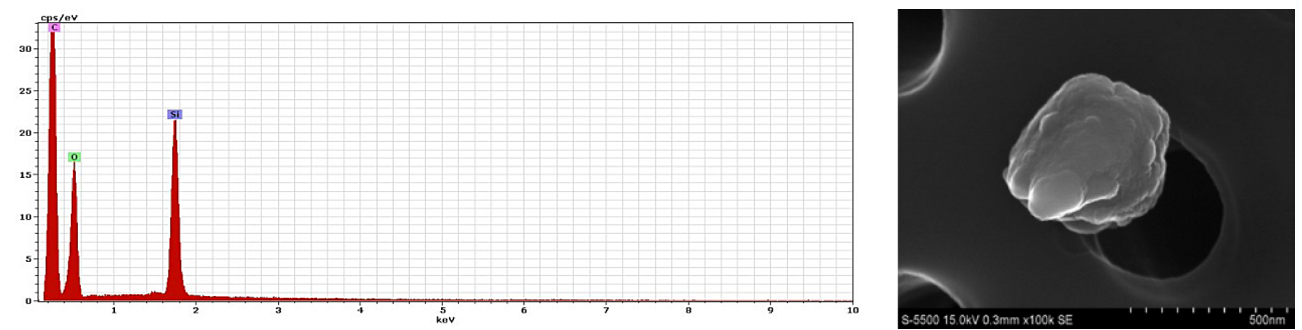

Figure 14. SEM-based EDS spectrum and SEI of a particle from re-suspended sample S1062 from Kostolac, Serbia. The silicon (Si) content points to a rounded quartz particle contained in the loess.

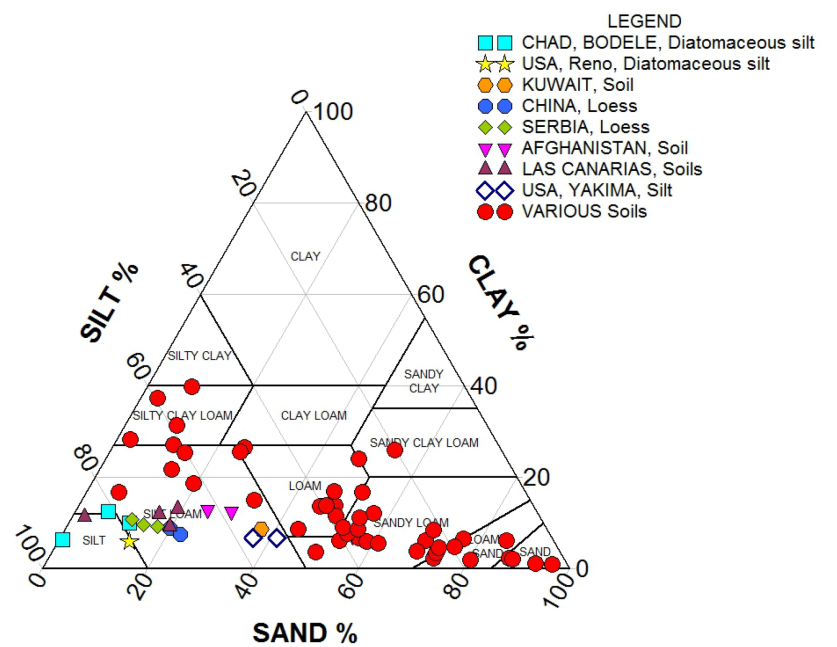

Figure 15. Size-class fractions grouped as clay $(<2 \mu \mathrm{m})$, silt $(2-$ $62.5 \mu \mathrm{m})$, and sand $(62.5-600 \mu \mathrm{m})$. Samples from regions with the greatest potential to be sources of airborne dust lie in the "silt loam" and "silt" fields with less than about $10 \%$ clay, including samples from known dust regions in Chad, China, Afghanistan, Kuwait, northwestern Africa, southeastern Europe, and parts of western USA.

The correlation matrix (Table 1) provides a general assessment of chemical species associated with specific minerals in the suite of samples. The high correlation of 0.91 between water soluble sodium $\left(\mathrm{Na}^{+}\right)$and sulfate $\left(\mathrm{SO}_{4}^{2-}\right)$ is ascribed to the mineral thenardite $\left(\mathrm{Na}_{2} \mathrm{SO}_{4}\right)$ identified by XRD in two samples (S1023, S1024) from Etosha Pan, a dry lakebed in Namibia. Some sodium $\left(\mathrm{Na}^{+}\right)$is also correlated to the chloride $\left(\mathrm{Cl}^{-}\right)$, pointing to the evaporite mineral halite $(\mathrm{NaCl})$, often found in dry lakebeds.

$\mathrm{Al}$ is highly correlated with $\mathrm{Fe}$, as well as $\mathrm{Ti}$ and $\mathrm{Mn}$, pointing to these elements occurring together or attached to clay minerals such as montmorillonite and palygorskite. Also, the correlation of $\mathrm{Si}$ with $\mathrm{Al}$ and $\mathrm{K}$ points to the clay mineral illite or possibly potassium feldspar. The correlation (0.42) between $\mathrm{Ca}$ and $\mathrm{Mg}$ is ascribed to these species occurring together in the carbonate mineral dolomite $\left(\mathrm{CaMg}\left[\mathrm{CO}_{3}\right]_{2}\right)$. There is also a distinct negative correlation between $\mathrm{Al}$ on the one side and $\mathrm{Ca}$ and $\mathrm{Mg}$ on the other, pointing to an inverse relationship between the clay minerals and the carbonates (calcite, dolomite) in the aerosol samples; i.e., the higher the clay content in the sample, the lower the carbonates, and vice versa. The inverse relationship between clays and carbonates shown by some samples is also evident in the plot of calcium (expressed as $\mathrm{CaO}$ ) against aluminum (expressed as $\mathrm{Al}_{2} \mathrm{O}_{3}$ ) (Fig. 16, Supplements $\mathrm{S} 4.4, \mathrm{~S} 4.6$ ).

The scatter of $\mathrm{CaO}$ values shown in Fig. 16 is ascribed to the fact that calcium occurs not only in calcite $\left(\mathrm{CaCO}_{3}\right)$ but also in dolomite $\left(\mathrm{CaMg}\left[\mathrm{CO}_{3}\right]_{2}\right)$ and to a lesser extent in plagioclase feldspars $\left(\mathrm{NaAlSi}_{3} \mathrm{O}_{8}-\mathrm{CaAl}_{2} \mathrm{Si}_{2} \mathrm{O}_{8}\right)$, gypsum $\left(\mathrm{CaSO}_{4} \cdot 2 \mathrm{H}_{2} \mathrm{O}\right)$, and other evaporite minerals.

There is a reasonably strong linear correlation of 0.79 between $\mathrm{Fe}$ and $\mathrm{Al}$ for the complete set of 165 samples (Table 1), with most (122) samples falling in one oblongshaped cluster with an average slope of 0.76 (Fig. 17). This subset of samples has an average $\mathrm{Fe}_{2} \mathrm{O}_{3}$ content of $4.76 \%$ for $\mathrm{PM}_{10}$ and $5.22 \%$ for $\mathrm{PM}_{2.5}$, with respective $\mathrm{Fe} / \mathrm{Al}$ ratios of 1.01 and 0.87 (Table 2). The $\mathrm{Fe} / \mathrm{Al}$ ratios for these two subsets of samples vary from 0.47 to 3.38 for $\mathrm{PM}_{10}$ and from 0.41 to 3.78 for $\mathrm{PM}_{2.5}$. This brackets the range found for re-suspended $\mathrm{PM}_{10}(\mathrm{Fe} / \mathrm{Al}=0.87-1.38)$ and $\mathrm{PM}_{2.5}(\mathrm{Fe} / \mathrm{Al}=0.74-1.10)$ samples from the Middle East (Engelbrecht et al., 2009b), similar to ambient $\mathrm{PM}_{2.5}$ samples $(\mathrm{Fe} / \mathrm{Al}=0.77-1.11)$ previously collected in the same region (Engelbrecht et al., 2008, 2009a). These are not unlike the $\mathrm{Fe} / \mathrm{Al}$ ratios of 0.95-1.85 measured by Jaafar et al. (2014) in the course of dust events in Beirut, Lebanon. Chemical analysis of five total suspended particle dust samples from western Iran (Najafi et al., 2014) yielded Fe / Al ratios in the range of 0.64-0.81. Al-Awadhi (2005) found the $\mathrm{Fe} / \mathrm{Al}$ mass ratio from fallout dust in Kuwait to vary on average from 0.23 for the light mineral fractions to 0.97 for the heavy mineral fractions.

A set of 28 Saharan dust samples collected from the Bodélé Depression in Chad (Bristow et al., 2010) were analyzed for a number of chemical species and have a $\mathrm{Fe} / \mathrm{Al}$ mass ratio in the range of $0.53-1.71$. In contrast, soil samples collected along the southern Sahel region in Mali (Fig. 17) were different (Roquin et al., 1990), with Fe / Al mass ratios for the ferricretes ranging from 2.95 to 3.43 . Prospero et al. (2001) found an average Fe / Al mass ratio of 0.55 for 
Table 1. Linear correlation coefficients between pairs of chemical species, with pairs ${ }^{\mathrm{a}}>0.9,{ }^{\mathrm{b}} 0.6$ to $0.9,{ }^{\mathrm{c}} 0.4$ to 0.59 , and ${ }^{\mathrm{d}}-0.4$ to -0.59 .

\begin{tabular}{lrrrrrrrrrrr}
\hline & $\mathrm{Si}$ & $\mathrm{Ti}$ & $\mathrm{Al}$ & $\mathrm{Fe}$ & $\mathrm{Mn}$ & $\mathrm{Ca}$ & $\mathrm{Mg}$ & $\mathrm{K}$ & $\mathrm{Na}^{+}$ & $\mathrm{CL}^{-}$ & $\mathrm{SO}_{4}^{2-}$ \\
\hline $\mathrm{Si}$ & 1 & & & & & & & & & & \\
$\mathrm{Ti}$ & 0.37 & 1 & & & & & & & & & \\
$\mathrm{Al}$ & $0.47^{\mathrm{c}}$ & $0.75^{\mathrm{b}}$ & 1 & & & & & & & & \\
$\mathrm{Fe}$ & 0.09 & $0.63^{\mathrm{b}}$ & $0.79^{\mathrm{b}}$ & 1 & & & & & & & \\
$\mathrm{Mn}$ & 0.32 & $0.60^{\mathrm{b}}$ & $0.41^{\mathrm{c}}$ & 0.21 & 1 & & & & & & \\
$\mathrm{Ca}$ & $-0.48^{\mathrm{d}}$ & -0.30 & $-0.40^{\mathrm{d}}$ & -0.35 & -0.06 & 1 & & & & & \\
$\mathrm{Mg}$ & -0.18 & -0.30 & $-0.41^{\mathrm{d}}$ & -0.32 & -0.01 & $0.424^{\mathrm{c}}$ & 1 & & & & \\
$\mathrm{~K}$ & $0.44^{\mathrm{c}}$ & 0.39 & 0.27 & -0.04 & $0.58^{\mathrm{c}}$ & -0.16 & -0.05 & 1 & & & \\
$\mathrm{Na}^{+}$ & -0.34 & -0.36 & -0.38 & -0.29 & -0.28 & -0.14 & 0.06 & -0.11 & 1 & & \\
$\mathrm{CL}^{-}$ & -0.15 & -0.23 & -0.22 & -0.23 & -0.11 & -0.04 & 0.18 & 0.04 & $0.48^{\mathrm{c}}$ & 1 & \\
$\mathrm{SO}_{4}^{2-}$ & -0.38 & -0.32 & -0.33 & -0.26 & -0.27 & -0.04 & 0.06 & -0.21 & $0.91^{\mathrm{a}}$ & $0.41^{\mathrm{c}}$ & \\
\hline
\end{tabular}

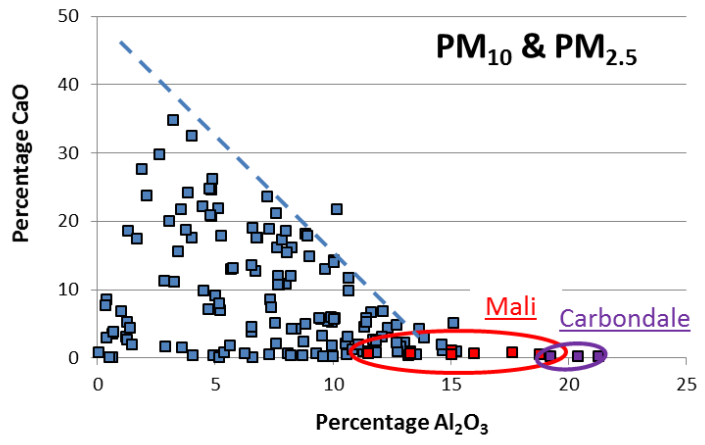

Figure 16. Triangular-shaped field for the majority of the 130 dust re-suspensions, with a maximum for $\mathrm{Al}_{2} \mathrm{O}_{3}$ of about $15 \%$ and $\mathrm{CaO}$ of less than approximately $50 \%$. The plot shows an inverse relationship between the two chemical species, with samples containing the highest $\mathrm{Al}_{2} \mathrm{O}_{3}$ also containing the lowest $\mathrm{CaO}$, and vice versa. This points in part to the substitution of, e.g., carbonates and gypsum for clay minerals or clay-like colloids. The clay-bearing (kaolinite) samples from Mali and Carbondale (circled) and several others lie along the $x$ axis, implying they contain no calcium-bearing minerals.

$\mathrm{PM}_{10}$ and $\mathrm{PM}_{2.5}$ samples collected in south-central Florida, having been transported across the Atlantic Ocean from Saharan Africa. Surface soils from Mongolia and China analyzed by Xuan (2005) were also in the lower range, with $\mathrm{Fe} / \mathrm{Al}=0.33-0.50$. Dust samples from Niger, Cabo Verde, Tunisia, and China, suspended on polycarbonate filters and analyzed by XRF, give concentrations of $6.2-8.7 \% \mathrm{Fe}_{2} \mathrm{O}_{3}$ and $\mathrm{Fe} / \mathrm{Al}$ ratios of 0.43-6.0 (Lafon et al., 2006). We suggest that differences in $\mathrm{Fe}$ and $\mathrm{Al}$ concentrations, and subsequent range in $\mathrm{Fe} / \mathrm{Al}$ ratios found by investigators, are not only due to chemical differences amongst the samples but also in part ascribed to different sampling and analytical procedures.

The high correlation between $\mathrm{Fe}$ and $\mathrm{Al}$ is attributed to the co-existence of oxide minerals (hematite, goethite, magnetite) with various clay minerals, chlorite, and other sili-

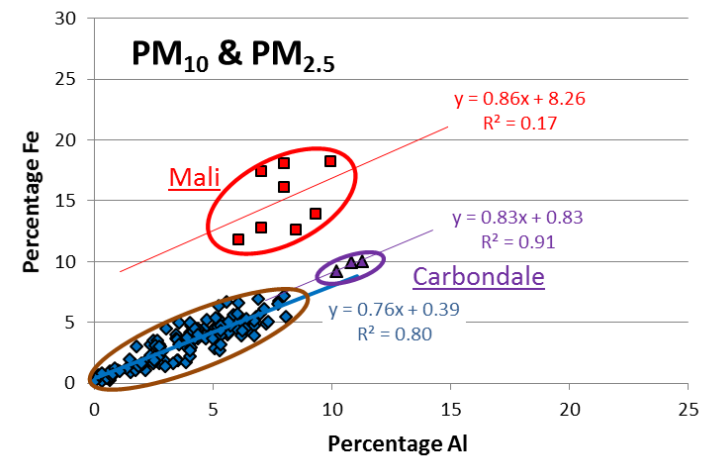

Figure 17. Plot showing the linear relationship between iron (Fe) and aluminum (Al) for 130 chemically analyzed soil resuspensions. Three sample clusters can be identified with most (122) falling in one field (brown oval) with an average Fe / Al slope of 0.76. Samples from Mali (red oval) and Carbondale (violet oval) have slightly higher slopes. The high correlation and tight cluster of the largest (122 samples) group imply that the iron $(\mathrm{Fe})$ is in part contained in the clay mineral structure or dispersed as colloidal oxyhydroxide in the clay-like amorphous matrix.

cates, in varying proportions, depending on factors of provenance, chemical weathering, and pedogenesis. Comparisons of chemical results of re-suspended soils from this study and those published on biotites (Deer et al., 1962) and clays (Weaver and Pollard, 1973) are shown in Table 2. Clay minerals identified by XRD and SEM include illite, palygorskite, and kaolinite, with montmorillonite in few samples. The average $\mathrm{Al}$ concentrations of the re-suspended soils $(3.58 \%$ for $\mathrm{PM}_{10}, 4.64 \%$ for $\mathrm{PM}_{2.5}$ ) (Table 2a, b) are substantially lower than those of chlorite $(22.06 \%)$ (Table 2d), illite $(13.94 \%)$ (Table 2e), montmorillonite (11.6\%) (Table 2f), or palygorskite $(6.73 \%$ ) (Table $2 \mathrm{~g}$ ). The Fe contents of the resuspended soils (ave. $3.33 \%$ for $\mathrm{PM}_{10}, 3.65 \%$ for $\mathrm{PM}_{2.5}$ ) are less or similar to those of chlorite $(2.21 \%)$, illite $(3.48 \%)$, montmorillonite $(2.79 \%)$, or palygorskite $(2.26 \%)$. The resultant $\mathrm{Fe} / \mathrm{Al}$ ratios for the re-suspensions are also greater 
Table 2. Average concentrations and elemental ratios for (a) $\mathrm{PM}_{10}$ and (b) $\mathrm{PM}_{2.5}$ re-suspensions from this study, (c) biotite (Deer et al., 1962 , Table 13), chlorite (Weaver and Pollard, 1973, Table XLII), illite (ditto, Table III), montmorillonite (ditto, Table XXV), and palygorskite (ditto, Table LII).

\begin{tabular}{|c|c|c|c|c|c|c|c|}
\hline \multirow{4}{*}{$N$ obs. } & \multicolumn{2}{|c|}{ Soil re-suspensions } & \multirow{3}{*}{$\begin{array}{r}\text { Biotite } \\
\text { (c) }\end{array}$} & \multirow{2}{*}{$\begin{array}{r}\text { Chlorite } \\
\text { (d) }\end{array}$} & \multirow{2}{*}{$\begin{array}{r}\text { Illite } \\
\text { (e) }\end{array}$} & \multirow{2}{*}{$\begin{array}{r}\text { Montmorillonite } \\
\text { (f) }\end{array}$} & \multirow{2}{*}{$\begin{array}{r}\text { Palygorskite } \\
(\mathrm{g})\end{array}$} \\
\hline & (a) & (b) & & & & & \\
\hline & 61 & 61 & & 7 & 24 & 101 & 15 \\
\hline & $\begin{array}{r}\mathrm{PM}_{10} \\
\text { Ave. (range) mass \% }\end{array}$ & $\begin{array}{r}\mathrm{PM}_{2.5} \\
\text { Ave. (range) mass \% }\end{array}$ & Ave. mass $\%$ & Ave. mass $\%$ & Ave. mass $\%$ & Ave. mass $\%$ & Ave. mass $\%$ \\
\hline $\mathrm{SiO}_{2}$ & $24.87(3.70-56.75)$ & $30.36(6.07-56.12)$ & 35.93 & 36.82 & 49.78 & 59.49 & 54.78 \\
\hline $\mathrm{TiO}_{2}$ & $0.51(0.03-1.71)$ & $0.53(0.03-1.74)$ & 2.61 & 0.74 & 0.42 & 0.25 & 0.10 \\
\hline $\mathrm{Al}_{2} \mathrm{O}_{3}$ & $6.76(0.38-12.77)$ & $8.77(0.33-15.23)$ & 19.06 & 41.70 & 26.35 & 21.93 & 12.73 \\
\hline $\mathrm{Fe}_{2} \mathrm{O}_{3}$ & $4.76(0.27-9.61)$ & $5.22(0.38-10.28)$ & 2.52 & 2.74 & 4.30 & 3.77 & 2.73 \\
\hline $\mathrm{FeO}$ & & & 16.40 & 0.38 & 0.61 & 0.20 & 0.45 \\
\hline $\mathrm{MgO}$ & $1.81(0.00-9.53)$ & $2.80(0.00-14.38)$ & 9.04 & 4.39 & 2.75 & 3.55 & 0.41 \\
\hline $\mathrm{CaO}$ & $9.98(0.25-29.74)$ & $9.53(0.19-34.84)$ & 0.27 & 0.88 & 0.32 & 1.18 & 1.00 \\
\hline $\mathrm{Na}_{2} \mathrm{O}$ & $1.87(0.01-38.51)$ & $1.83(0.00-29.86)$ & 0.62 & 0.17 & 0.25 & 0.82 & 8.68 \\
\hline $\mathrm{K}_{2} \mathrm{O}$ & $1.80(0.22-3.33)$ & $2.03(0.32-4.02)$ & 8.68 & 1.20 & 7.02 & 0.34 & 0.43 \\
\hline $\mathrm{Si}$ & $11.62(1.73-26.50)$ & $14.18(2.83-26.21)$ & 16.78 & 17.19 & 23.25 & 27.78 & 25.58 \\
\hline $\mathrm{Ti}$ & $0.30(0.02-1.03)$ & $0.32(0.02-1.04)$ & 1.57 & 0.44 & 0.25 & 0.15 & 0.06 \\
\hline $\mathrm{Al}$ & $3.58(0.20-6.75)$ & $4.64(0.18-8.06)$ & 10.08 & 22.06 & 13.94 & 11.60 & 6.73 \\
\hline $\mathrm{Fe}^{\mathrm{III}}$ & $3.33(0.19-6.72)$ & $3.65(0.27-7.18)$ & 1.76 & 1.92 & 3.01 & 2.64 & 1.91 \\
\hline $\mathrm{Fe}^{\mathrm{II}}$ & - & - & 12.74 & 0.29 & 0.47 & 0.15 & 0.35 \\
\hline $\mathrm{Mg}$ & $1.09(0.00-5.75)$ & $1.69(0.00-8.67)$ & 5.45 & 2.65 & 1.66 & 2.14 & 0.25 \\
\hline $\mathrm{Ca}$ & $7.13(0.18-21.26)$ & $6.81(0.13-24.91)$ & 0.17 & 0.63 & 0.23 & 0.84 & 0.72 \\
\hline $\mathrm{Na}$ & $1.39(0.01-28.58)$ & $1.36(0.00-22.15)$ & 0.46 & 0.13 & 0.18 & 0.61 & 6.44 \\
\hline $\mathrm{K}$ & $1.49(0.18-2.76)$ & $1.68(0.27-3.34)$ & 7.20 & 0.99 & 5.83 & 0.28 & 0.35 \\
\hline \multicolumn{8}{|c|}{ Mass ratios } \\
\hline $\mathrm{Si} / \mathrm{Al}$ & $5.51(2.09-70.13)$ & $5.49(1.86-80.76)$ & 1.67 & 0.81 & 1.67 & 2.39 & 4.04 \\
\hline $\mathrm{Ti} / \mathrm{Al}$ & $0.09(0.05-0.29)$ & $0.07(0.03-0.29)$ & 0.16 & 0.01 & 0.02 & 0.01 & 0.00 \\
\hline $\mathrm{Fe} / \mathrm{Al}$ & $1.01(0.47-3.38)$ & $0.87(0.41-3.78)$ & 1.44 & 0.07 & 0.25 & 0.24 & 0.27 \\
\hline $\mathrm{Mg} / \mathrm{Al}$ & $1.37(0.0-28.38)$ & $1.71(0.0-48.98)$ & 0.54 & 0.13 & 0.12 & 0.18 & 0.01 \\
\hline $\mathrm{Na} / \mathrm{Al}$ & $2.63(0.0-83.46)$ & $1.52(0.00-34.1)$ & 0.09 & 0.00 & 0.01 & 0.05 & 1.05 \\
\hline $\mathrm{K} / \mathrm{Al}$ & $0.58(0.1-3.56)$ & $0.51(0.09-3.08)$ & 0.71 & 0.03 & 0.42 & 0.02 & 0.01 \\
\hline
\end{tabular}

(a)
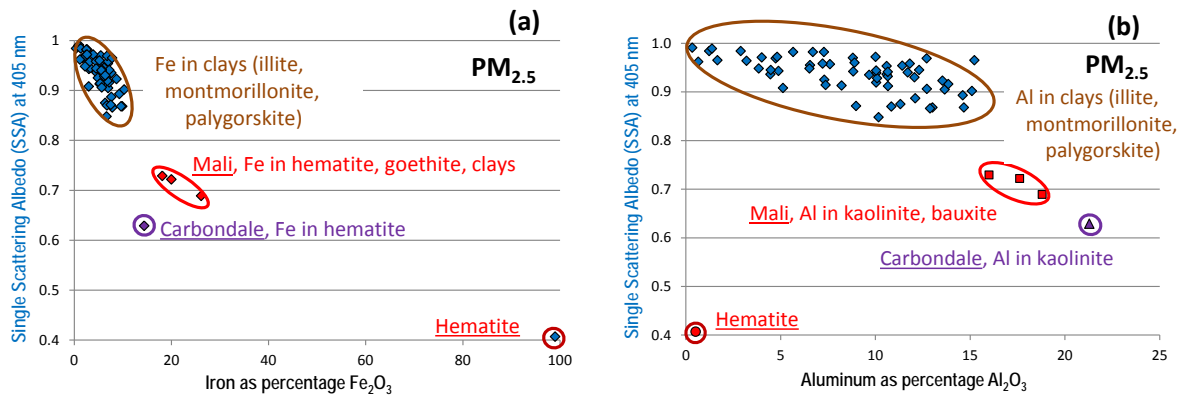

Figure 18. Single scattering albedo (SSA) at $405 \mathrm{~nm}$ for the $\mathrm{PM}_{2.5}$ fractions, against (a) $\mathrm{Fe}_{2} \mathrm{O}_{3}$ and (b) $\mathrm{Al}_{2} \mathrm{O}_{3}$ content, illustrating the relationship to dust mineralogy. Most (122 samples) falling in the brown ellipse contain iron (Fe) partly in clays (illite, montmorillonite, palygorskite) and oxyhydroxides (hematite, goethite) and as colloids in an amorphous clay-like matrix. This group has SSA greater than 0.85, while those samples which contain all or part of the iron (Fe) as individual oxyhydroxides (hematite, goethite) have SSA below 0.75 .

(ave. 1.01 for $\mathrm{PM}_{10}, 0.87$ for $\mathrm{PM}_{2.5}$ ) than those of chlorite (0.07), illite (0.25), montmorillonite $(0.24)$, or palygorskite (0.27) (Table $2 \mathrm{~d}-\mathrm{g}$ ). The greater $\mathrm{Fe} / \mathrm{Al}$ ratios for the resuspended soil samples point to the presence of Fe-bearing minerals in the particles other than clays. It is evident that although some Fe is contained in the crystal structures of the chlorite, illite, montmorillonite, palygorskite and other clay minerals, the remaining $\mathrm{Fe}$ is contained in hematite, 
goethite, or magntite, as well as iron-bearing silicates such as biotite, chlorite, amphibole, and pyroxene, all minerals identified in the sieved soil samples by optical microscopy and XRD. Also, the grouping of the majority (122) of the samples (Fig. 17) and the high correlation coefficient of 0.79 between $\mathrm{Fe}$ and $\mathrm{Al}$ (Table 1) point to a strong chemical interrelationship amongst the Fe-bearing clays, Fe-oxides (goethite, hematite, magnetite), and other silicates such as micas (biotite, muscovite) and chlorite. Recent studies (Reynolds et al., 2014a, b; Kars et al., 2015), applying a combination of Mössbauer spectroscopy, magnetic measurements, reflectance spectroscopy, and scanning electron microscopy (SEM), provide evidence of nanometer size $(<20 \mathrm{~nm})$ particles of hematite, goethite, and magnetite associated with clay particles. Similarly, from magnetic measurements on the Callovian-Oxfordian claystones in the Paris Basin, Kars et al. (2015) suggest nanoparticles of goethite to be dispersed in the clay-like matrix. Fordham (1990), from investigations by electron microscopy and XRD, concluded that biotite underwent chemical weathering at particle edges and along cleavage plains to form finely divided interstratified flakes of illite and iron oxides in the clay-like matrix, which Borchard et al. (1971) had identified as colloidal coatings of amorphous clay-like particles in volcanic ash in soils.

To explain the elevated concentrations of $\mathrm{Fe}, \mathrm{Ti}, \mathrm{Ca}, \mathrm{K}$, and $\mathrm{Fe} / \mathrm{Al}$ ratios in the soil re-suspensions, compared to those in crystalline clay minerals (illite, montmorillonite, and palygorskite) (Table 2), we propose that particles of $\mathrm{PM}_{10}$ and $\mathrm{PM}_{2.5}$ are to a large extent composed of nano-size particles of micas, clays, metal oxides, and ions of potassium $\left(\mathrm{K}^{+}\right)$, calcium $\left(\mathrm{Ca}^{2+}\right)$, and sodium $\left(\mathrm{Na}^{+}\right)$evenly dispersed as a colloid, or adsorbed in amorphous clay-like matrix. These composite particles are suggested to be secondary products of biotite and other ferromagnesian particles are formed by chemical weathering and pedogenesis, forming particle coatings, individual particles, or interstitial material with quartz, feldspars, and other silicates.

\subsubsection{Optical and mineral interrelationships}

SSA for each of the re-suspended $\mathrm{PM}_{2.5}$ samples measured at three wavelengths: blue $(405 \mathrm{~nm})$, green $(532 \mathrm{~nm})$, and red $(781 \mathrm{~nm})$ on re-suspended $\mathrm{PM}_{2.5}$ dust samples are given in Supplement S3.1 and S3.2. The SSA of mineral dust aerosols is determined by size distribution, morphology, and complex refractive index (Jeong and Nousiainen, 2014; Moosmüller and Arnott, 2009; Sokolik et al., 2001). In our case, constraints were placed on the size distributions by the use of a $\mathrm{PM}_{2.5}$ size selective inlet (Supplement S3.2), limiting the particle size for the samples to an average geometric mean diameter of $1.19 \mu \mathrm{m}$, with a standard deviation $0.11 \mu \mathrm{m}$. The aspect ratios of particles in the samples varied in the geometric mean range of 1.37 to 1.70 (Supplement S5.4). The relationships between $\mathrm{SSA}$, iron $\left(\mathrm{as}_{2} \mathrm{Fe}_{3}\right)$, and aluminum
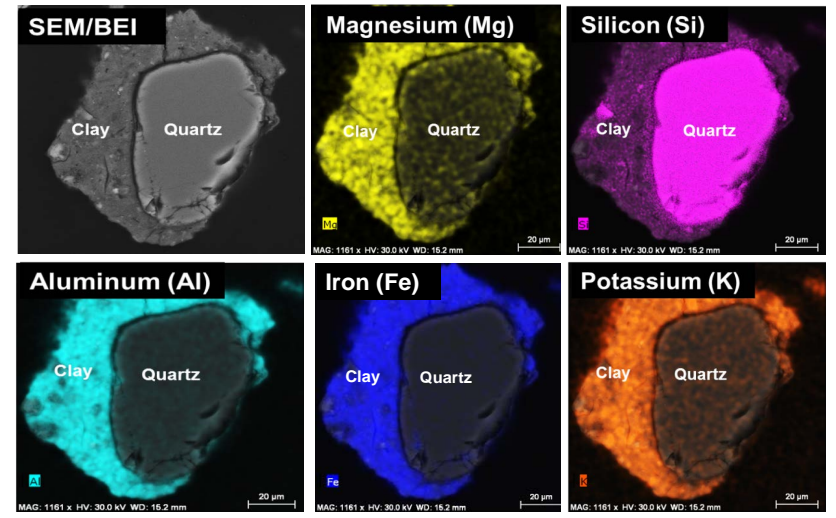

Figure 19. Sample S1056 from Lake Eyre, South Australia. SEMgenerated backscattered electron image (BEI) and chemical maps of a quartz grain with a prominent coating. The coating is composed of an amorphous clay matrix containing colloidal particles of sheet silicates (clay, mica), oxyhydroxides (goethite, hematite), and adsorbed ions, explaining the uniform distribution of magnesium $(\mathrm{Mg})$, silicon $(\mathrm{Si})$, aluminum $(\mathrm{Al})$, iron $(\mathrm{Fe})$, and potassium $(\mathrm{K})$.

(as $\mathrm{Al}_{2} \mathrm{O}_{3}$ ) mass fractions at $405 \mathrm{~nm}$ are shown in Fig. 18a and b (also Supplement S4.5).

As was previously shown (Moosmüller et al., 2012), there is a direct relationship between the iron (expressed as $\mathrm{Fe}_{2} \mathrm{O}_{3}$ ) content of the samples and the resultant SSA, most evident at $405 \mathrm{~nm}$ (Fig. 18a). From the mineralogical information gathered from the optical microscopy (Supplement S2.1), XRD (Supplement S2.2), and SEM-based individual particle analysis (Supplement S5.1, S5.2), the sample chemical compositions evidently depict specific mineral groups. Shown in Fig. 18a and b are one large and three substantially smaller mineral groups, the main one being the amorphous Fe-bearing clays (illite, montmorillonite, palygorskite), and the other from Mali where the $\mathrm{Fe}$ is predominantly in the hematite or goethite with kaolinite (not containing Fe) as the dominant clay mineral (Roquin et al., 1990). The Carbondale sample was found to contain the iron mineral hematite and the clay mineral kaolinite while the hematite group contained nearly pure $\mathrm{Fe}_{2} \mathrm{O}_{3}$ (Fig. 18a). From the differences in the distribution patterns, it is evident that the SSA is not only determined by the $\mathrm{Fe}$ content alone but by the minerals in which Fe occurs. In the large clay group (illite, montmorillonite, palygorskite) the $\mathrm{Fe}$ is contained in the crystal structure (Fig. 19), but may also occur as nanometer-sized colloidal particles of hematite or goethite in the amorphous clay matrix.. In the case of the samples from Mali, the $\mathrm{Fe}$ is contained in variable proportions of hematite or goethite particles (Fig. 20), since no iron per se is contained in the kaolinite crystal structure. The Carbondale sample contains hematite as the only Fe-bearing mineral. Absorption in the $404 \mathrm{~nm}$ (also $532 \mathrm{~nm}$ ) is stronger for hematite and goethite than for Fe-bearing clay minerals, with the resultant lower 


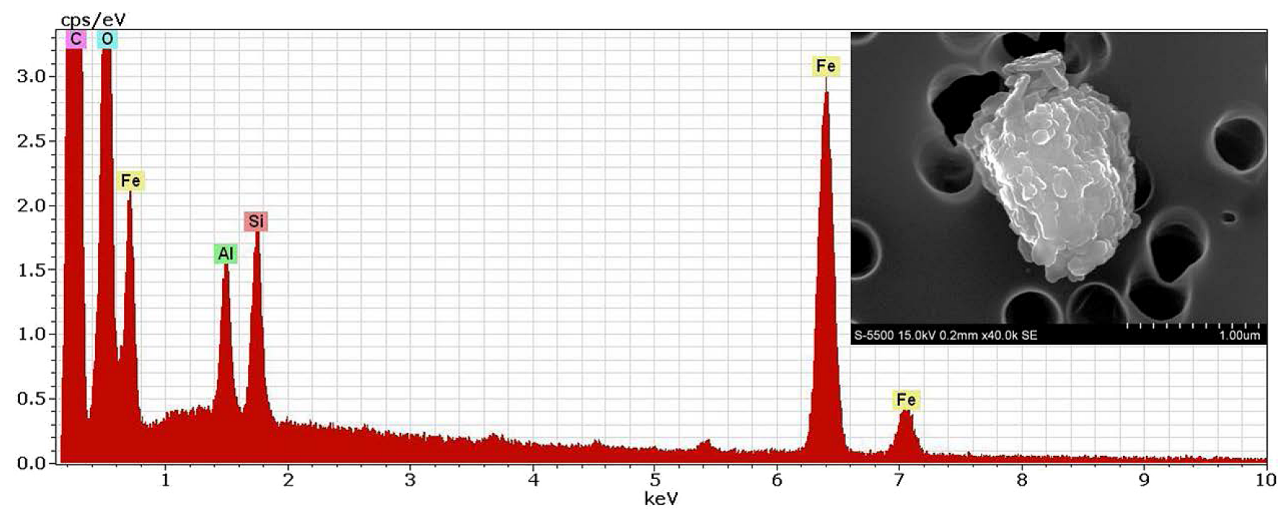

Figure 20. SEM-based EDS spectrum and SEI of a particle from re-suspended sample S1009 from Mali. The composite particle contains iron $(\mathrm{Fe})$ as the mineral goethite $(\mathrm{FeO}(\mathrm{OH}))$ and/or hematite $\left(\mathrm{Fe}_{2} \mathrm{O}_{3}\right)$ together with silicon $(\mathrm{Si})$ and aluminum $(\mathrm{Al})$ in the clay mineral kaolinite.

SSA for the dust samples where hematite and goethite were identified as individual mineral grains.

As expected, pure hematite (S1000) has the lowest SSA $(0.407)$ at $405 \mathrm{~nm}$; this also holds true at $532 \mathrm{~nm}$ $(\mathrm{SSA}=0.487)$ and $781 \mathrm{~nm}(\mathrm{SSA}=0.976)$. Among dust samples, Carbondale (S1065) has the lowest SSA at $405 \mathrm{~nm}$ $(\mathrm{SSA}=0.629)$ and at $532 \mathrm{~nm}(\mathrm{SSA}=0.864)$. However, at $781 \mathrm{~nm}$ the Carbondale sample has a slightly higher SSA (0.991) than two of the Mali samples (S1010: SSA $=0.981$ and S1011: SSA $=0.988$ ). The three Mali samples (S1009, S1010, S1011) also have the next lowest SSA values at $405 \mathrm{~nm}$ (see Fig. 18) and at $532 \mathrm{~nm}$. The highest SSA values were reported for the Etosha Fischer Pan sample S1022 from Namibia with SSA $=0.991(405 \mathrm{~nm}), 0.997(532 \mathrm{~nm})$, and $0.999(781 \mathrm{~nm})$, closely followed by those of two Bodélé Depression samples (S1049, S1050) and one from Peavine Mountain with identical values of SSA $=0.982(405 \mathrm{~nm})$, $0.995(532 \mathrm{~nm})$, and $0.999(781 \mathrm{~nm})$.

\section{Conclusions}

The purpose of our study was to provide an understanding of the optical, physical, mineralogical, and chemical interrelationships of a suite of re-suspended dust samples. It can be argued that soil samples re-suspended in the laboratory may be representative of surface wind-generated dust, part of which (e.g., $\mathrm{PM}_{2.5}$ ) could be lofted and transported over large distances across the globe.

However, it is recognized that dusts may be modified as they mix with other aerosols and age under changing meteorological conditions and over time, in some cases forming aggregates of larger particles. In our study, SEM-based SEIs of the re-suspended dust samples are evidence of such mineral clusters, as well as of coatings on quartz, feldspar, and other mineral grains, similar to that reported on in ambient aerosols (Cuadros et al., 2015; Díaz-Hernández and Párraga, 2008; Engelbrecht et al., 2009a; Jeong et al., 2014). The suite of surface soil samples investigated here is representative of many recognized dust source regions of the globe. At the time of this study, we did not have samples from all dust regions of North Africa, the Middle East, Asia, Australia, or South America.

A holistic approach (Smuts, 1986) to the analysis of mineral dusts provided us with a comprehensive understanding of their optical, physical, mineralogical, and chemical properties, and useful information that can be applied in remote sensing, modeling, global climate, health-related, and other studies.

The individual analytical procedures each provided important perspectives towards a better understanding of mineral dusts. Laser-based particle size analysis of the $<600 \mu \mathrm{m}$ sieved sample provided information on the silt content of the soils and the likelihood of dust being suspended when soil surfaces are disturbed. Petrographic microscopy on the $>75,<125 \mu \mathrm{m}$ sieved soil fractions readily identified the minerals such as quartz, feldspars, micas, and carbonates, which make up the coarse fractions of dust. XRD provided semi-quantitative information on the mineral content of the $<38 \mu \mathrm{m}$ sieved soil fractions. The chemical analyses (XRF, ICP-MS, ICP-OES, IC) of the $\mathrm{PM}_{10}$ and $\mathrm{PM}_{2.5}$ size fractions could be related to their mineralogy, including their clay (illite, palygorskite, montmorillonite, kaolinite) and iron oxide (hematite, goethite) relationships, as well as to characterizing dust sources. Qualitative information on the mineralogy of the dusts, obtained from optical microscopy, XRD, and SEM, allowed for their chemical compositions to be calculated to normative mineral compositions. Such normative mineral compositions are useful when comparing samples to each other. SEM, furthermore, provided information on the individual particle size, shape, and chemical composition which in many cases could be linked to the sample mineralogies. Surface coatings of clays, oxides, and amorphous phases often mask the identity of the underlying mineral grains of quartz and feldspars, a feature which needs to 
be considered when interpreting SEM and optical measurements.

Two mineralogically distinct phase assemblages are distinguished. The first and largest group of samples is described as colloids in amorphous clay (allophane) (Kars et al., 2015) clusters, surface coatings on particles, and interstitial soils, characterized here by an average $\mathrm{Fe} / \mathrm{Al}$ ratio of 0.94 (range 0.41-3.78). The Fe and Al contents as well as the Fe / Al ratios are evidence of interstitial layers of iron (goethite) and aluminum (gibbsite), oxyhydroxides (Birkeland, 1999), and possibly the presence of nano-sized colloidal particles of oxides (hematite). The abundance of potassium $\left(\mathrm{K}^{+}\right)$points to this element being adsorbed on the amorphous clay layers, or nano-sized flakes of residual primary mica (biotite) or illite, retained in the amorphous colloid. The second and smaller group includes samples from the subtropical region south of the Sahel, where the clay mineral in the laterites was found to be largely kaolinite, with the $\mathrm{Fe}$ as individual oxide (hydroxide) mineral grains of hematite and goethite (Roquin et al., 1990).

The SSA measured on the $\mathrm{PM}_{2.5}$ samples, as clearly seen at the blue (i.e., $405 \mathrm{~nm}$ ) wavelength, varied not only with the Fe content of the samples but also with the mineralogy, i.e., whether Fe was contained in a clay mineral (illite, montmorillonite, palygorskite), or as nano-size colloidal particles of hematite and goethite in the amorphous clay-like matrix.

Understanding the dust mineralogy, especially of the clay minerals and iron oxides, is of prime importance to our understanding of the optical properties of airborne mineral dusts. This paper greatly expands on our previous results from a limited sample set, showing a linear relationship between SSA and iron content (Moosmüller et al., 2009), here illustrating that this relationship is also controlled by sample mineralogy and mineralogical interrelationships.

\section{Data availability}

Mineralogical, chemical, physical, and optical results are presented in tables and figures in the Supplement to this paper. Requests for data from this study can be directed to Johann Engelbrecht (johann@dri.edu) at the Desert Research Institute (DRI) in Reno, Nevada.

\section{The Supplement related to this article is available online at doi:10.5194/acp-16-10809-2016-supplement.}

Author contributions. Johann Engelbrecht was the principal investigator and manager for the research project, responsible for the design of the program, configuring the hardware, experimental activities, data interpretation, compilation of results, and compiling this paper. Hans Moosmüller was the co-principal investigator for the project, formulating the problem, advising on the experimental design, interpreting results, and compiling parts of this paper. Samuel Pincock was responsible for a major part of the experimental work in the re-suspension laboratory, including the collection and validation of measurements. R. K. M. Jayanty from RTI International was responsible for the chemical analysis of filter samples. Gary Casuccio and Traci Lersch from RJ Lee Group were responsible for the SEM-based individual particle analysis.

Acknowledgements. The following persons or organizations provided grab soil samples for this program: US Army Public Health Command for samples from the Middle East, including Iraq (6), Kuwait (5), Afghanistan (3), Djibouti (1), Qatar (1), and UAE (1); Virginia Garrison for samples from Mali (3) and Cabo Verde (1); Edward Derbyshire for a sample from China (1); Earle Williams for samples from Chad (3); Samuel Marx for samples from Australia (3); Estelle Stegmann for samples from Namibia (3); Johann Engelbrecht for samples from USA (8), Canary Islands (8), Serbia (3), and Botswana (4); Henry Sun for a sample from Chile (1); Ross Edwards for samples from China (4); Michał Skiba for a sample from Morocco (1); Davis Zhu for samples from USA (2); Steven Kohl for a sample from USA (1).

We acknowledge analytical support from the laboratories of RTI International and RJ Lee Group. Greatly appreciated is technical support from the Desert Research Institute (DRI), including from Larry Sheets for help with the design and building of the resuspension chamber, and Dave Campbell for installing and calibrating the equipment.

This project was funded under the US Army Medical Research and Materiel Command grant W81XWH-11-2-0220.

Edited by: D. Knopf

Reviewed by: R. Reynolds and one anonymous referee

\section{References}

Adams, K. D. and Sada, D. W.: Black Rock Playa, Northwestern Nevada: Physical Processes and Aquatic Life, Desert Research Institute, Reno, Nevada, 1-20, 2010.

Alastuey, A., Querol, X., Castillo, S., Escudero, M., Avila, A., Cuevas, E., Torres, C., Romero, P., Exposito, F., and Garcia, O.: Characterisation of TSP and $\mathrm{PM}_{2.5}$ at Izaña and Sta. Cruz de Tenerife (Canary Islands, Spain) during a Saharan Dust Episode (July 2002), Atmos. Environ., 39, 4715-4728, 2005.

Al-Awadhi, J. M.: Dust fallout characteristics in Kuwait: a case study, Kuwait J. Sci. Eng., 32, 135-151, 2005.

Al-Dousari, A. and Al-Awadhi, J.: Dust fallout in northern Kuwait, major sources and characteristics, Kuwait J. Sci. Eng., 39, 171187, 2012.

Alexander, J. M., Meland, B., Laskina, O., Young, M. A., Grassian, V. H., and Kleiber, P. D.: Light scattering from diatomaceous earth aerosol, J. Quant. Spectrosc. Ra., 125, 33-37, doi:10.1016/j.jqsrt.2013.04.013, 2013.

Arnott, W. P., Moosmüller, H., Rogers, C. F., Jin, T., and Bruch, R.: Photoacoustic spectrometer for measuring light absorption by aerosol: Instrument Description, Atmos. Environ., 33, 28452852, 1999. 
Arnott, W. P., Moosmüller, H., and Walker, J. W.: Nitrogen Dioxide and Kerosene-Flame Soot Calibration of Photoacoustic Instruments for Measurement of Light Absorption by Aerosols, Rev. Sci. Instrum., 71, 4545-4552, 2000.

Avila, A., Queralt-Mitjans, I., and Alarçon, M.: Mineralogical composition of African dust delivered by red rains over northeastern Spain, J. Geophys. Res., 102, 21977-21996, 1997.

Ben-Ami, Y., Koren, I., Rudich, Y., Artaxo, P., Martin, S. T., and Andreae, M. O.: Transport of North African dust from the Bodélé depression to the Amazon Basin: a case study, Atmos. Chem. Phys., 10, 7533-7544, doi:10.5194/acp-10-7533-2010, 2010.

Bergametti, G., Gomes, L., Coudé-Gaussen, G., Rognon, P., and Le Coustumer, M. N.: African dust observed over Canary Islands: source-regions identification and transport pattern for some summer situations, J. Geophys. Res., 94, 14855-14864, 1989.

Bergstrom, R. W., Pilewskie, P., Russell, P. B., Redemann, J., Bond, T. C., Quinn, P. K., and Sierau, B.: Spectral absorption properties of atmospheric aerosols, Atmos. Chem. Phys., 7, 5937-5943, doi:10.5194/acp-7-5937-2007, 2007.

Betzer, P., Carder, K., Duce, R., and Merrill, J.: Long range transport of giant mineral aerosol particles, Nature, 336, 568-571, 1988.

Birkeland, P. W.: Soils and Geomorphology, Third Edition, Oxford University Press, Inc., New York, 430 pp., 1999.

Blanco, A., Dee Tomasi, F., Filippo, E., Manno, D., Perrone, M. R., Serra, A., Tafuro, A. M., and Tepore, A.: Characterization of African dust over southern Italy, Atmos. Chem. Phys., 3, 21472159, doi:10.5194/acp-3-2147-2003, 2003.

Borchard, G. A., Harward, M. E., and Knox, E. G.: Trace element concentration in amorphous clays of volcanic ash soils in Oregon, Clay. Clay. Miner., 19, 375-382, 1971.

Bristow, C. S., Hudson-Edwards, K. A., and Chappell, A.: Fertilizing the Amazon and equatorial Atlantic with West African dust, Geophys. Res. Lett., 37, L14807, doi:10.1029/2010GL043486, 2010.

Buch, M. W. and Rose, D.: Mineralogy and geochemistry of the sediments of the Etosha Pan Region in northern Namibia: a reconstruction of the depositional environment, J. Afr. Earth Sci., 22, 355-378, 1996.

Burbank, D. W. and Jijun, L.: Age and palaeoclimatic significance of the loess of Lanzhou, north China, Nature, 316, 429-431, 1985.

Buringh, P.: Soils and Soil Conditions in Iraq, Directorate General of Agricultural Research and Projects, Ministry of Agriculture, Baghdad, Republic of Iraq, 1-322, 1960.

Caquineau, S., Magonthier, M.-C., Gaudichet, A., and Gomes, L.: An improved procedure for the X-ray diffraction analysis of lowmass atmospheric dust samples, Eur. J. Mineral., 9, 157-166, 1997.

Chadwick, O. A., Derry, L. A., Vitousek, P. M., Huebert, B. J., and Hedin, L. O.: Changing sources of nutrients during four million years of ecosystem development, Nature, 397, 491-497, 1999.

Chappell, A., Warren, A., O'Donoghue, A., Robinson, A., Thomas, A., and Bristow, C. S.: The implications for dust emission modeling of spatial and vertical variations in horizontal dust flux and particle size in the Bodélé Depression, Northern Chad, J. Geophys. Res., 113, D04214, doi:10.1029/2007JD009032, 2008.

Choate, L. M., Ranville, J. F., Bunge, A. L., and Macalady, D. L.: Dermally Adhered Soil: 2. Reconstruction of Dry-Sieve Particle-
Size Distributions from Wet-Sieve Data, Integrated Environmental Assessment and Management, 2, 385-390, 2006.

Chow, J. C. and Watson, J. G.: Ion Chromatography in elemental analysis of airborne particles, Elemental Analysis of Airborne Particles, edited by: Landsberger, S., a. M. C., Gordon and Breach Science, Amsterdam, 97-137, 1999.

Chung, F. H.: Quantitative interpretation of X-ray diffraction patterns of mixtures. I. Matrix-flushing method for quantitative multicomponent analysis, J. Appl. Crystallogr., 7, 519-525, doi:10.1107/S0021889874010375, 1974.

Chýlek, P. and Wong, J.: Effect of Absorbing Aerosol on Global Radiation Budget, Geophys. Res. Lett., 22, 929-931, 1995.

Coudé-Gaussen, G., Rognon, P., Bergametti, G., Gomes, L., Strauss, B., Gros, J. M., and le Coustumer, M.-N.: Saharan dust on Fuerteventura Island (Canaries): chemical and mineralogical characteristics, air mass trajectories and probable sources, J. Geophys. Res., 92, 9753-9771, 1987.

Criado, C. and Dorta, P.: An unusual "blood rain" over the Canary Islands (Spain). The storm of January 1999, J. Arid Environ., 55, 765-783, doi:10.1016/S0140-1963(02)00320-8, 2003.

Cuadros, J., Diaz-Hernandez, J. L., Sanchez-Navas, A., and GarciaCasco, A.: Role of clay minerals in the formation of atmospheric aggregates of Saharan dust, Atmos. Environ., 120, 160-172, 2015.

Deer, W. A., Howie, R. A., and Zussman, J.: Rock-Forming Minerals, Vol. 3, Sheet Silicates, Longman, Green and Co. Ltd, London, 1962.

Derbyshire, E., Meng, X., and Kemp, R. A.: Provenance, transport and characteristics of modern aeolian dust in western Gansu Province, China, and interpretation of the Quaternary loess record, J. Arid Environ., 39, 497-516, 1998.

Díaz-Hernández, J. L. and Párraga, J.: The nature and tropospheric formation of iberulites: Pinkish mineral microspherulites, Geochim. Cosmochim. Ac., 72, 3883-3906, 2008.

Draxler, R. R., Gillette, D. A., Kirkpatrick, J. S., and Heller, J.: Estimating $\mathrm{PM}_{10}$ air concentrations from dust storms in Iraq, Kuwait and Saudi Arabia, Atmos. Environ., 35, 4315-4330, 2001.

Engelbrecht, J. P., McDonald, E. V., Gillies, J. A., and Gertler, A. W.: Department of Defense Enhanced Particulate Matter Surveillance Program (EPMSP), Desert Research InstituteContract Number: W9124R-05-C-0135/SUBCLIN 000101-ACRNAB, 57, 2008.

Engelbrecht, J. P., McDonald, E. V., Gillies, J. A., Jayanty, R. K. M., Casuccio, G., and Gertler, A. W.: Characterizing mineral dusts and other aerosols from the Middle East - Part 1: Ambient sampling, Inhal. Toxicol., 21, 297-326, 2009a.

Engelbrecht, J. P., McDonald, E. V., Gillies, J. A., Jayanty, R. K. M., Casuccio, G., and Gertler, A. W.: Characterizing mineral dusts and other aerosols from the Middle East - Part 2: Grab samples and re-suspensions, Inhal. Toxicol., 21, 327-336, 2009b.

Engelbrecht, J. P., Gillies, J. A., Etyemezian, V., Kuhns, H., Baker, S. E., Zhu, D., Nikolich, G., and Kohl, S. D.: Controls on mineral dust emissions at four arid locations in the western USA, Aeolian Res., 6, 41-54, 2012.

Engelbrecht, J. P., Menéndez, I., and Derbyshire, E.: Sources of $\mathrm{PM}_{2.5}$ impacting on Gran Canaria, Spain, Catena, 117, 119-132, 2014.

Engelstaedter, S., Tegen, I., and Washington, R.: North African Dust Emissions and Transport, Earth-Sci. Rev., 79, 73-100, 2006. 
Esteve, V., Rius, J., Ochando, L. E., and Amigó, J. M.: Quantitative $\mathrm{X}$-ray diffraction phase analysis of coarse airborne particulate collected by cascade impactor sampling, Atmos. Environ., 31, 3963-3967, doi:10.1016/S1352-2310(97)00257-4, 1997.

Field, J. P., Belnap, J., Breshears, D. D., Neff, J. C., Okin, G. S., Whicker, J. J., Painter, T. H., Ravi, S., Reheis, M. C., and Reynolds, R. L.: The ecology of dust, Front. Ecol. Environ., 8, 423-430, doi:10.1890/090050, 2010.

Fordham, A. W.: Weathering of biotite into dioctahedral clay minerals, Clay Minerals, 25, 51-63, 1990.

Formenti, P., Andrea, M. O., Lange, L., Roberts, G., Cafmeyer, J., Rajta, I., Maenhaut, W., Holben, B. N., Artaxo, P., and Lelieveld, J.: Saharan dust in Brazil and Surinam during the Large-Scale Biosphere-Atmosphere Experiment in Amazonia (LBA) - Cooperative LBA Regional Experiment (CLAIRE) in March 1998, J. Geophys. Res., 106, 14919-14934, 2001.

Fubini, B. and Fenoglio, I.: Toxic potential of mineral dusts, Elements, 3, 407-414, 2007.

Gee, G. W. and Or, D.: Particle-size analysis, in: Methods of Soil Analysis: Part 4 - Physical Methods, No. 5, edited by: Dane, J. H. and Topp, G. C., Soil Science Society of America, Madison, WI, 255-293, 2002.

Gelado-Caballero, M. D., Rodríguez, M. J., Hernández, J. J., Brito De Acevedo, E. M., Llinás, O., Collado, C., Cardona, P., and López, P.: Dust deposition fluxes to north-eastern subtropical Atlantic (Canary Islands), Geophys. Res. Abstr., EGU2005-08399, EGU General Assembly 2005, Vienna, Austria, 2005.

Ghio, A. J., Kummarapurupu, S. T., Tong, H., Soukup, J. M., Dailey, L. A., Boykin, E., Gilmour, M. I., Ingram, P., Roggli, V. L., Goldstein, H. L., and Reynolds, R. L.: Biologic effects of desert dust in respiratory epithelial cells and a murine model, Inhal. Toxicol., 26, 299-309, doi:10.3109/08958378.2014.888109, 2014.

Gillies, J. A., Kuhns, H., Engelbrecht, J. P., Uppapalli, S., Etyemezian, V., and Nikolich, G.: Particulate emissions from U.S. Departement of Defense artillery backblast testing, J. Air Waste Manage., 57, 551-560, 2007.

Gillies, J. A., Etyemezian, V., Kuhns, H., McAlpine, J. D., King, J., Uppapalli, S., Nikolich, G., and Engelbrecht, J. P.: Dust emissions created by low-level rotary-winged aircraft flight over desert surfaces, Atmos. Environ., 44, 1043-1053, 2010.

Ginoux, P., Prospero, J. M., Gill, T. E., Hsu, N. C., and Zhao, M.: Global-scale attribution of anthropogenic and natural dust sources and their emission rates based on Modis Deep Blue aerosol products, Rev. Geophys., 50, RG3005, doi:10.1029/2012rg000388, 2012.

Goudie, A. S. and Middleton, N. J.: Saharan dust storms: nature and consequences, Earth-Sci. Rev., 56, 179-204, doi:10.1016/S00128252(01)00067-8, 2001

Hassan, T., Moosmüller, H., and Chung, C. E.: Coefficients of an Analytical Aerosol Forcing Equation Determined with a MonteCarlo Radiation Model, J. Quant. Spectrosc. Ra., 164, 129-136, 2015.

Heintzenberg, J.: Experiment over Southern Morocco: Overview and introduction, Tellus B, 61, 2-11, 2009.

Jaafar, M., Baalbaki, R., Mrad, R., Daher, N., Shihadeh, A., Sioutas, C., and Saliba, N. A.: Dust episodes in Beirut and their effect on the chemical composition of coarse and fine particulate matter, Sci. Total Environ., 496, 75-83, 2014.
Jahn, R. and Stahr, K.: Development of soils and site qualities on basic volcanoclastics with special reference to the semiarid environment of Lanzarote, Canary Islands, Spain, Rev. Mex. Cienc. Geol., 13, 104-112, 1996.

Jeong, G. Y. and Nousiainen, T.: TEM analysis of the internal structures and mineralogy of Asian dust particles and the implications for optical modeling, Atmos. Chem. Phys., 14, 7233-7254, doi:10.5194/acp-14-7233-2014, 2014.

Jeong, G. Y., Kim, J. Y., Seo, J., Kim, G. M., Jin, H. C., and Chun, Y.: Long-range transport of giant particles in Asian dust identified by physical, mineralogical, and meteorological analysis, Atmos. Chem. Phys., 14, 505-521, doi:10.5194/acp-14-505-2014, 2014.

Kahlaf, F. I., Al-Kadi, A., and Al-Saleh, S.: Mineralogical composition and potential sources of dust fallout deposits in Kuwait, Sediment. Geol., 42, 225-278, 1985.

Kandler, K., Benker, N., Bundke, U., Cuevas, E., Ebert, M., Knippertz, P., Rodríguez, S., Schütz, L., and Weinbruch, S.: Chemical composition and complex refractive index of Saharan mineral dust at Izaña, Tenerife (Spain) derived by electron microscopy, Atmos. Environ., 41, 8058-8074, 2007.

Kandler, K., Schütz, L., Deutscher, C., Ebert, M., Hofmann, H., Jäckel, S., Jaenicke, R., Knippertz, P., Lieke, K., Massling, A., Petzold, A., Schladitz, A., Weinzierl, B., Wiedensohler, A., Zorn, S., and Weinbruch, S.: Size distribution, mass concentration, chemical and mineralogical composition and derived optical parameters of the boundary layer aerosol at Tinfou, Morocco, during SAMUM 2006, Tellus B, 61, 32-50, 2009.

Kars, M., Lerouge, C., Grangeon, S., Aubourg, C., Tournassat, C., Madé, B., and Claret, F.: Identification of nanocrystalline goethite in reduced clay formations: Application to the Callovian-Oxfordian formation of Bure (France), Am. Mineral., 100, 1544-1553, 2015.

Kohfeld, K. E. and Harrison, S. P.: Glacial-interglacial changes in dust deposition on the Chinese Loess Plateau, Quaternary Sci. Rev., 22, 1859-1878, 2003.

Kok, J. F.: A scaling theory for the size distribution of emitted dust aerosols suggests climate models underestimate the size of the global dust cycle, P. Natl. Acad. Sci. USA, 108, 1016-1021, doi:10.1073/pnas.1014798108, 2011.

Koren, I., Kaufman, Y. J., Washington, R., Todd, M. C., Rudich, Y., Martins, J. V., and Rosenfeld, D.: The Bodélé Depression: a single spot in the Sahara that provides most of the mineral dust to the Amazon forest, Environ. Res. Lett., 1, 014005, doi:10.1088/1748-9326/1/1/014005, 2006.

Lafon, S., Sokolik, I. N., Rajot, J. L., Caquineau, S., and Gaudichet, A.: Characterization of iron oxides in mineral dust aerosols: Implications for light absorption, J. Geophys. Res., 111, D21207, doi:10.1029/2005JD007016, 2006.

Lawrence, C. R. and Neff, J. C.: The contemporary physical and chemical flux of aeolian dust: A synthesis of direct measurements of dust deposition, Chem. Geol., 267, 46-63, doi:10.1016/j.chemgeo.2009.02.005, 2009.

Lewis, G. C., Fosberg, M. A., Falen, A. L., and Miller, B. J.: Identification of loess by particle size distribution using the Coulter Counter TA II1, Soil Sci., 137, 172-176, 1984.

Lewis, K., Arnott, W. P., Moosmüller, H., and Wold, C. E.: Strong spectral variation of biomass smoke light absorption and single scattering albedo observed with a novel dual-wavelength 
photoacoustic instruments, J. Geophys. Res., 113, D16203, doi:10.1029/2007JD009699, 2008.

Maring, H., Savoie, D. L., Izaguirre, M. A., McCormick, C., Arimoto, R., Prospero, J. M., and Pilinis, C.: Aerosol physical and optical properties and their relationship to aerosol composition in the free troposphere at Izaña, Tenerife, Canary Islands, during July 1995, J. Geophys. Res., 105, 14677-14700, 2000.

Maring, H., Savoie, D. L., Izaguirre, M. A., Custals, L., and Reid, J. S.: Mineral dust aerosol size distribution change during atmospheric transport, J. Geophys. Res., 108, 8592, doi:10.1029/2002JD002536, 2003.

Marković, S. B., Hambach, U., Catto, N., Jovanović, M., Buggle, B., Machalett, B., Zöller, L., Glaser, B., and Frechen, M.: Middle and Late Pleistocene loess sequences at Batajnica, Vojvodina, Serbia, Quaternary Int., 198, 255-266, 2009.

Marković, S. B., Hambach, U., Stevens, T., Kukla, G. J., Heller, F., McCoy, W. D., Oches, E. A., Buggle, B., and Zöller, L.: The last million years recorded at the Stari Slankamen (Northern Serbia) loess-palaeosol sequence: revised chronostratigraphy and longterm environmental trends, Quaternary Sci. Rev., 30, 1142-1154, 2011.

Marx, S. K., McGowan, H. A., and Kamber, B. S.: Long-range dust transport from eastern Australia: a proxy for Holocene aridity and ENSO induced climate variability, Earth Planet. Sc. Lett., 282, 167-177, 2009.

McGowan, H. A. and Clark, A.: A vertical profile of $\mathrm{PM}_{10}$ dust concentrations measured during a regional dust event identified by MODIS Terra, western Queensland, Australia, J. Geophys. Res., 113, F02S03, doi:10.1029/2007JF000765, 2008.

McGowan, H. A., Kamber, B. S., McTainsh, G. H., and Marx, S. K.: High resolution provenancing of long travelled dust deposition in the Southern Alps, New Zealand, Geomorphology, 69, 208-221, 2005.

McKay, C. P., Friedmann, E. I., Gomez-Silva, B., Caceres, L., Andersen, D. T., and Landheim, R.: Temperature and moisture conditions for life in the extreme arid region of the Atacama Desert: four years of observations including the El Nino of 1997-1998, Astrobiology, 3, 393-406, 2003.

McTainsh, G. H., Nickling, W. G., and Lynch, A. W.: Dust deposition and particle size in Mali, West Africa, CATENA, 29, 307322, doi:10.1016/S0341-8162(96)00075-6, 1997.

Menéndez, I., Díaz-Hernandez, J. L., Mangas, J., Alonso, I., and Sánchez-Soto, P. J.: Airborne dust accumulation and soil development in the North-East sector of Gran Canaria (Canary Island, Spain), J. Arid Environ., 71, 57-81, 2007.

Menéndez, I., Derbyshire, E., Engelbrecht, J. P., Suchodoletz, H., von Zöller, L., Dorta, P., Carrillo, T., and Rodríguez de Castro, F.: Saharan dust and the aerosols on the Canary Islands: Past and present, Chapter 2, in: Airborne Particulates, edited by: Cheng, M. and Liu, W., Nova Science Publishers, Inc., New York, 39-80, 2009.

Menéndez, I., Pérez-Chacón, E., Mangas, J., Tauler, E., Engelbrecht, J. P., Derbyshire, E., Cana, L., and Alonso, I.: Dust deposits on La Graciosa Island (Canary Islands, Spain): texture, mineralogy and a case study of recent dust plume transport, Catena, 117, 133-144, 2014.

Middleton, N., Yiallouros, P., Kleanthous, S., Kolokotroni, O., Schwartz, J., Dockery, D. W., Demokritou, P., and Koutrakis, P.: A 10-year time-series analysis of respiratory and cardio- vascular morbidity in Nicosia, Cyprus: the effect of short-term changes in air pollution and dust storms, Environ. Health, 7, 39, doi:10.1186/1476-069X-7-39, 2008.

Middleton, N. J. and Goudie, A. S.: Saharan dust: Sources and trajectories, Transactions of the Institute of British Geographers, New Series, 26, 165-181, 2001.

Mizota, C. and Matsuhisa, Y.: Isotopic evidence for the eolian origin of quartz and mica in soils developed on volcanic materials in the Canary Archipelago, Geoderma, 66, 167-332, doi:10.1016/0016-7061(95)00004-8, 1995.

Molinaroli, E.: Mineralogical Characterization of Saharan Dust with a View to its Final Destination in Mediterranean Sediments, in: The Impact of Desert Dust Across the Mediterranean Environmental Science and Technology Library, edited by: Guerzoni Stefano, R. C., Kluwer Academic Publishers, 153-162, 1996.

Molinaroli, E., Guerzoni, S., and Rampazzo, G.: Contribution of Saharan dust to the Central Mediterranean Basin, Geol. Soc. Am. Special Paper, 284, 303-312, 1993.

Moosmüller, H. and Arnott, W. P.: Particle optics in the Rayleigh regime, J. Air Waste Manage., 59, 1028-1031, doi:10.3155/1047-3289.59.9.1028, 2009.

Moosmüller, H., Chakrabarty, R. K., and Arnott, W. P.: Aerosol light absorption and its measurement: a review, J. Quant. Spectrosc. Ra. 110, 844-878, 2009.

Moosmüller, H., Engelbrecht, J. P., Skiba, M., Frey, G., Chakrabarty, R. K., and Arnott, W. P.: Single scattering albedo of fine mineral dust aerosols controlled by iron concentration, J. Geophys. Res., 117, D11210, doi:10.1029/2011JD016909, 2012.

Moreno, A., Targarona, J., Henderiks, J., Canals, M., Freudenthal, T., and Meggers, H.: Orbital forcing of dust supply to the North Canary Basin over the last $250 \mathrm{kyr}$, Quaternary Sci. Rev., 20, 1275-1376, doi:10.1016/S0277-3791(00)00184-0, 2001.

Moreno, T., Amato, F., Querol, X., Alastuey, A., Elvira, J., and Gibbons, W.: Bedrock controls on the mineralogy and chemistry of $\mathrm{PM}_{10}$ extracted from Australian desert sediments, Environ. Geol., 57, 411-420, 2009.

Muhs, D. R., Budahn, J., Skipp, G., Prospero, J. M., Patterson, D., and Bettis III, E. A.: Geochemical and mineralogical evidence for Sahara and Sahel dust additions to Quaternary soils on Lanzarote, eastern Canary Islands, Spain, Terra Nova, 22, 399-410, 2010.

Müller, T., Schladitz, A., Massling, A., Kaaden, N., Kandler, K., and Wiedensohler, A.: Spectral absorption coefficients and imaginary parts of refractive indices of Saharan dust during SAMUM-1, Tellus B, 61, 79-95, 2009.

Najafi, M. S., Khoshakhllagh, F., Zamanzadeh, S. M., Shirazi, M. H., Samadi, M., and Hajikh, S.: Characteristics of TSP loads during the Middle East springtime dust storm (MESDS) in Western Iran, Arabian Journal of Geosciences, 7, 5367-5381, 2014.

Navarro-González, R., Rainey, F. A., Molina, P., Bagaley, D. R., Hollen, B. J., Rosa, J. d. 1., Small, A. M., Quinn, R. C., Grunthaner, F. J., Cáceres, L., Gomez-Silva, B., and McKay, C. P.: Mars-like soils in the Atacama Desert, Chile, and the dry limit of microbial life, Science, 302, 1018-1021, 2003.

Neff, J. C., Reynolds, R. L., Munson, S., Fernandez, D., and Belnap, $\mathrm{J}$.: The role of dust storms in atmospheric particle concentrations at two sites in the western U.S., J. Geophys. Res., 118, 1120111212, doi:10.1002/jgrd.50855, 2013. 
Norboo, T., Angchuk, P. T., Yahya, M., Karnak, S. R., Pooley, F. D., Corrin, B., Kerr, I. H., Bruce, N., and Ball, K. P.: Silicosis in a Himalayan village population: role of environmental dust, Thorax, 46, 341-343, 1991.

Oldfield, F., Chiverrell, R. C., Lyons, R., Williams, E., Shen, Z., Bristow, C., Bloemendal, J., Torrent, J., and Boyle, J. F.: Discriminating dusts and dusts sources using magnetic properties and hematite:goethite ratios of surface materials and dust from North Africa, the Atlantic and Barbados, Aeolian Res., 13, 91104, 2014.

Pérez-Marrero, J., Llinás, O., Maroto, L., Rueda, M. J., and Cianca, A.: Saharan dust storms over the Canary Islands during winter 1998 as depicted from the advanced very high-resolution radiometer, Deep-Sea Res. Pt. II, 49, 3465-3479, 2002.

Petzold, A., Rasp, K., Weinzierl, B., Esselborn, M., Hamburger, T., Dörnbrack, A., Kandler, K., Schütz, L., Knippertz, P., Fiebig, M., and Virkkula, A.: Saharan dust absorption and refractive index from aircraft-based observations during SAMUM 2006, Tellus B, 61, 118-130, 2009.

Prospero, J. M., Olmez, I., and Ames, M.: Al and Fe in $\mathrm{PM}_{2.5}$ and $\mathrm{PM}_{10}$ suspended particles in South-Central Florida: The impact of the long range transport of African mineral dust, Water Air Soil Poll., 125, 291-317, 2001.

Prospero, J. M., Ginoux, P., Torres, O., Nicholson, S. E., and Gill, T. E.: Environmental characterization of global sources of atmospheric soil dust identified with the Nimbus 7 Total Ozone Mapping Spectrometer (TOMS) absorbing aerosol product, Rev. Geophys., 40, 1002, doi:10.1029/2000RG000095, 2002.

Pye, K.: Aeolian dust and dust deposits, Academic Press, London, 1987.

Reheis, M. C.: Dust deposition downwind of Owens (dry) Lake, 1991-1994: preliminary findings, J. Geophys. Res., 102, 25999 26008, 1997.

Revel-Rolland, M., De Deckker, P., Delmonte, B., Hesse, P. P., Magee, J. W., Basile-Doelsch, I., Grousset, F., and Bosch, D.: Eastern Australia: A possible source of dust in East Antarctica interglacial ice, Earth Planet. Sc. Lett., 249, 1-13, doi:10.1016/j.epsl.2006.06.028, 2006.

Reynolds, R. L., Cattle, S. R., Moskowitz, B. M., Goldstein, H. L., Yauk, K., Flagg, C. B., Berquó, T. S., Kokaly, R. F., Morman, S., and Breit, G. N.: Iron oxide minerals in dust of the Red Dawn event in eastern Australia, September 2009, Aeolian Res., 15, $1-$ 13, 2014a.

Reynolds, R. L., Goldstein, H. L., Moskowitz, B. M., Bryant, A. C., Skiles, S. M., Kokaly, R. F., Flagg, C. B., Yauk, K., Berquó, T., Breit, G., Ketterer, M., Fernandez, D., Miller, M. E., and Painter, T. H.: Composition of dust deposited to snow cover in the Wasatch Range (Utah, USA): Controls on radiative properties of snow cover and comparison to some dust-source sediments, Aeolian Res., 15, 73-90, 2014b.

Rietveld, H. M.: A profile refinement method for nuclear and magnetic structures, J. Appl. Crystallogr., 2, 65-71, doi:10.1107/S0021889869006558, 1969.

Roquin, C., Dandjinou, T., Freyssinet, P., and Pion, J. C.: The correlation between geochemical data and SPOT satellite imagery of lateritic terrain in southern Mali, J. Geochem. Explor., 32, 149168, 1989.

Roquin, C., Freyssinet, P., Zeegers, H., and Tardy, Y.: Element distribution patterns in laterites of southern Mali: Consequence for geochemical prospecting and mineral exploration, Appl. Geochem., 5, 303-315, 1990.

Satheesh, S. K. and Moorthy, K. K.: Radiative effects of natural aerosols: A review, Atmos. Environ., 39, 2089-2110, 2005.

Sayyah, A., Horenstein, M. N., and Mazumder, M. K.: Energy yield loss caused by dust deposition on photovoltaic panels, Sol. Energy, 107, 576-604, doi:10.1016/J.Solener.2014.05.030, 2014.

Scheuvens, D., Schütz, L., Kandler, K., Ebert, M., and Weinbruch, S.: Bulk composition of northern African dust and its source sediments - A compilation, Earth-Sci. Rev., 116, 170-194, 2013.

Schladitz, A., Müller, T., Kaaden, N., Massling, A., Kandler, K., Ebert, M., Weinbruch, S., Deutscher, C., and Wiedensohler, A.: In situ measurements of optical properties at Tinfou (Morocco) during the Saharan mineral dust experiment SAMUM 2006, Tellus B, 61, 64-78, 2009.

Shao, Y.: A model for mineral dust emission, J. Geophys. Res., 106, 20239-20254, doi:10.1029/2001JD900171, 2001.

Smedman, G.: An investigation of the diatoms from four Tertiary lake beds in western Nevada, Paleobios no. 9, University of California, Museum of Paleontology in Berkeley, 16 pp., 1969.

Smuts, J. C.: Holism and Evolution, The Gestalt Journal Press, Inc., Gouldsboro ME, USA, 361 pp., 1986.

Sokolik, I. N., Winker, D. M., Bergametti, G., Gillette, D. A., Carmichael, G., Kaufman, Y. J., Gomes, L., Schuetz, L., and Penner, J. E.: Introduction to special section: outstanding problems in quantifying the radiative impacts of mineral dust, J. Geophys. Res., 106, 18015-18027, 2001.

Sturges, W. T., Harrison, R. M., and Barrie, L. A.: Semi-quantitative $\mathrm{X}$-ray diffraction analysis of size fractionated atmospheric particles, Atmos. Environ., 23, 1083-1098, 1989.

Stuut, J.-B., Zabel, M., Ratmeyer, V., Helmke, P., Schefuß, E., Lavik, G., and Schneider, R.: Provenance of present-day eolian dust collected off NW Africa, J. Geophys. Res., 110 D04202, doi:10.1029/2004JD005161, 2005.

Sun, J., Kohfeld, K. E., and Harrison, S. P.: Records of aeolian dust deposition on the Chinese Loess Plateau during the Late Quaternary, Technical Report - Max Planck Institute for Biochemistry, Jena, Germany, 318 pp., 2000.

Tanaka, T. Y. and Chiba, M.: A Numerical Study of the Contributions of Dust Source Regions to the Global Dust Budget, Global Planet. Change, 52, 88-104, 2006.

Tegen, I., Heinold, B., Todd, M., Helmert, J., Washington, R., and Dubovik, O.: Modelling soil dust aerosol in the Bodélé depression during the BoDEx campaign, Atmos. Chem. Phys., 6, 43454359, doi:10.5194/acp-6-4345-2006, 2006.

Todd, M. C., Washington, R., Martins, V., Dubovik, O., Lizcano, G., M'Bainayel, S., and Engelstaedter, S.: Mineral dust emission from the Bodèlè Depression, Chad during BoDEx. 2005, J. Geophys. Res., 112, D06207, doi:10.1029/2006JD007170, 2007.

US EPA: Compendium of Methods for the Determination of Inorganic Compounds in Ambient Air, Compendium Method IO-3.3, Determination of metals in ambient particulate matter using Xray fluorescence (XRF) spectroscopy, EPA/625/R-96/010, 3.3-13.3-32, 1999.

van Staveren, H. J., Moes, C. J. M., van Marie, J., Prahl, S. A., and van Gemert, M. J. C.: Light scattering in Intralipid-10\% in the wavelength range of 400-1100 nm, Appl. Optics, 30, 4507-4514, 1991. 
Viana, M. M., Querol, X., Alastuey, A., Cuevas, E., and Rodríguez, S.: Influence of African dust on the levels of atmospheric particulates in the Canary Islands air quality network, Atmos. Environ., 36, 5861-5875, 2002.

Von Hoyningen-Huene, W., Dinter, T., Kokhanovsky, A. A., Burrows, J. P., Wendisch, M., Bierwirth, E., Müller, D., and Diouri, M.: Measurements of desert dust optical characteristics at Porte au Sahara during SAMUM, Tellus B, 61, 206-215, 2009.

von Suchodoletz, H., Kühn, P., Hambach, U., Dietze, M., Zöller, L., and Faust, D.: Loesslike and palaeosol sediments from Lanzarote (Canary Islands/Spain) - indicators of Palaeoenvironmental change during the Late Quaternary, Palaeogeogr. Palaeocl., 278, 71-87, 2009.

von Suchodoletz, H., Glaser, B., Thrippleton, T., Broder, T., Zang, U., Eigenmann, R., Kopp, B., Reichert, M., and Zöller, L.: The influence of Saharan dust deposits on La Palma soil properties (Canary Islands, Spain), Catena, 103, 44-52, 2013.

Washington, R. and Todd, M. C.: Atmospheric controls on mineral dust emission from the Bodélé Depression, Chad: the role of the low level jet, Geophys. Res. Lett., 32, L17701, doi:10.1029/2005GL023597, 2005.

Watson, J. G.: 2002 Critical Review - Visibility: Science and regulation, J. Air Waste Manage., 52, 626-713, 2002.

Watson, J. G., Chow, J. C., and Frazier, C. A.: X-ray fluorescence analysis of ambient air samples, in: Air Sampling Instruments for Evaluation of Atmospheric Contaminants, edited by: Cohen, B. S. and Herring, S. V., Cincinnati, OH, 51-57, 1999.

Weaver, C. E. and Pollard, L. D.: The chemistry of clay minerals, Developments in Sedimentology 15, Elsevier, Amsterdam, 1973.
White, B. R., Lacchia, B. M., Greeley, R., and Leach, R. N.: Aeolian behavior of dust in a simulated Martian environment, J. Geophys. Res., 102, 25629-25640, 1997.

Wiggs, G. F. S., O’Hara, S., Wegerdt, J., van der Meer, J., Small, I., and Hubbard, R.: The dynamics and characteristics of aeolian dust in the dryland Central Asia: possible impacts on human exposure and respiratory health in the Aral Sea basin, Geographical J., 169, 142-157, 2003.

Wilkerson, G., Milliken, M., Saint-Amand, P., and Saint-Amand, D.: Roadside Geology and Mining History, Owens Valley and Mono Basin, U.S. Bureau of Land Management Buena Vista Museum of Natural History, 134 pp., 2007.

Williamson, D., Jackson, M., Banerjee, S. K., and Petit-Maire, N.: The magnetism of a glacial aeolianite sequence from Lanzarote (Canary Islands): coupling between luvic calcisol formation and Saharan dust trapping processes during wet deposition events off northwestern Sahara, Geophys. J. Int., 157, 1090-1104, 2004.

Xuan, J.: Emission inventory of eight elements, Fe, Al, K, Mg, Mn, $\mathrm{Na}, \mathrm{Ca}$ and $\mathrm{Ti}$, in dust source region of East Asia, Atmos. Environ., 39, 813-821, doi:10.1016/j.atmosenv.2004.10.029, 2005.

Zarei, M.: Weathering and neoformation of minerals in soils formed from volcanites at Lanzarote (Canary Islands, Spain), $\mathrm{PhD}$, Berlin, 1989.

Zender, C. S., Bian, H. S., and Newman, D.: Mineral dust entrainment and deposition (dead) model: Description and 1990s dust climatology, J. Geophys. Res., 108, 4416, doi:10.1029/2002JD002775, 2003. 